\title{
TOWARD OPTIMAL IAND USE: PROPERTY TAX POLICY AND LAND USE PLANNING
}

Land use planners and tax policy formulators are two distinct professional groups. Until recently, each group has meticulously avoided contact with the other. ${ }^{1}$ It is important to direct the attention of both of these professional groups to the interrelation of fiscal policy and land use planning. Fiscal policy is often a moving force behind planning decisions, and taxation often determines the pattern, time, character and planning of land development. As an instrument of planning, taxation is seldom part of the professional planner's training. Similarly, the tax expert is seldom versed in land use planning. Viewing taxation as the orderly assessment and collection of revenues, he is unconcerned with the effect of property tax on land use. The complexity of urban life forces governmental agencies to rely heavily on the tools of land use planning. An analysis of the interrelationship between land use planning and property taxation should therefore be valuable to all those planning on a regional scale in the San Francisco Bay Area.

This Comment surveys the newly awakened interest of planners and economists in the interrelation of land use planning and taxation. ${ }^{2}$ Two major problems will be discussed. ${ }^{3}$ Part I considers the existing tax and

1 Hagman, Land-Use Planning Throngh Taxation, 6 Current MUN. Prob. 345 (1965).

2 Evidence of the new awakening of interest in this field of scholarship is apparent in the recent series of research inonographs published by the Urban Land Institute (ULI). In addition, two recent books may stand as cornerstones for future analysis. J. HEmunRUN, Real Estate Taxes and Urban Housdro (1966); D. Netzer, Economics of the Property TAX (1966).

3 Two further areas of study are beyond the scope of this Comment. The first is the use of specific property tax incentives to attract new industry. The second is the impact of federal taxation on land use planning. For a general discussion of the second area see J. Pickard, Changme Urban Land Uses as Affercted by Taxation (ULI Research Monograph No. 6, 1962).

For a discussion of the income tax law and slums see Sporn, Some Contributions on the Income Tax Law to the Growth and Prevalence of Shums, 59 CoLuar. L. REv. 1026 (1959); Blum \& Dunham, Income Tax Law and Shums: Some Further Reflections, 60 Coluax. L. Rev. 447 (1960) (answer to Sporn; Sporn, Slums and the Income Tax: A Brief Rejoinder, 60 Cortus. L. Rev. 454 (1960) (rejoinder to Blum \& Dunham). Sporn concentrates attention on redepreciation and advocates fixing a useful hife and allowing a building to be depreciated only once over the original capital investment. This denies a stepped up basis to the subsequent purchasers. Blum and Dunham take issue with this proposal.

For a discussion of the adverse effects of capital gains treatment of land profits as tending to promote speculation and artificial inflation of land values see Wolfe, Taxation and Development, in Planning 1962, at 107 (selected papers from the Nat'l Planning Conference of the American Soc'y of Planning Officials). Wolfe advocates taxing land profits at ordinary rates. Today's Taxes Harness the Profit Motive Backwards: They Abet Speculation, but Penalize Development, House and HoMr, Aug. 1960, at 137. This article 
its impact on land use throughout the central city, suburbs and urban fringe areas of the modern metropolis. In the central cities the property tax seems to discourage new construction, remodeling and replacement while encouraging slums. In suburban areas competition for high base taxpayers produces suboptimal land use and tax shelters. In the fringe areas sprawl is producing increasing pressures on farmers. Part II deals with methods proposed to remedy the suboptimal effects of the existing tax. Part IIA examines short range devices designed to remedy specific problems with only minor substantive changes in the property tax base. Such short range devices include: exemption, abatements, and classification combined with special assessment. In Part IIB these short range devices are rejected in favor of a more comprehensive reevaluation of the entire property tax. Part IIC then discusses major changes in the property tax structure such as a change to gross rentals, British rates, net income, site value, user charges and land value increments. A combination of structural changes including site value, user charges and land value increment taxes is proposed to resolve regional planning problems.

Empirical data on the interrelation of taxation and land use planning in the Bay Area is generally unavailable; most information comes from

points out that to qualify for capital gains the investor must show he is not a dealer in real estate or that he is using the land in a trade or business other than real estate. In the latter case losses may be offset against ordinary income. If the property sold is a residence and the seller buys a new residence within one year, the sale is tax free. The article goes on to point out that with little effort a commuter inay learn to "reside" over a considerable investment.

For a suggestion that revenues from capital gains taxes on sales of land be returned to local government umits as an earmarked subsidy to provide property tax rehef see Moffitt, Planning and Assessing Practice, 42 LAND EcoN. 371, 377 (1966).

For a discussion of the adverse effects of failure to tax imputed gross rent on owner occupied housing see D. Laidler, The Income Tax Incentive to Owner Occupation of Housing, Oct. 5, 1963 (unpublished thesis in Center for Real Estate and Urban Economics Library, University of California at Berkeley). Goode, Imputed Rent of Ower Occupied Dwellings under the Income Tax, $15 \mathrm{~J}$. of FINANCE 504 (1960). Goode argues that the present system of property taxation discriminates against the renter and favors the homeowner over other investors thus encouraging homeowning. He poimts out that exclusions and deductions for mortgage interest and property taxes paid favor high inconie owners over those with low incomes. To the extent income taxation encourages homeowning, it: (1) increases demand for single family over inultiple dwellings, (2) favors suburb or fringe development over central areas (except in the case of cooperative apartments which have other tax advantages), (3) stimulates demand for high priced units, (4) causes minor price increases for owners and decreases for renters, and (5) produces a rise in land values due to increased demand for owner occupied housing which uses inore land space than rental housing. Even if we assume homeownership to be a worthwhile pohicy objective, Goode concludes that exemption of imputed rent works in the right direction but is ineffective. This is true because the strongest incentive is given to those with the highest incounes who need it least. His argument falters when Goode attempts to devise a feasible means of administering a tax on miputed gross rent. Laidler reaches substantially the same conclusions as Goode. 
studies in selected cities on the East Coast. More research on this problem is urgently needed. The conclusions reached in this Comment, however, should be as relevant to planners in California and the San Francisco Bay Area as in other parts of the country. The discussion in this Comment should aid in the formation of issues for future cooperative study by planners, economists and lawyers interested in the impact of taxation on land use planning.

\section{I}

PROPERTY TAX-LAND USE INTERRETATION

In the United States the property tax is increasing in importance. Revenue from the property tax has been expanding about eight per cent per year and in 1964 exceeded twenty billion dollars for the first time; local property tax revenue rose from 2.6 per cent of the gross national product in 1953 to 3.5 per cent in $1964 .^{4}$

The average United States real property tax rate is about 1.5 per cent of the full market value of taxable land and improvements. There is no uniform national property tax system. During the Nineteenth Century, in the heyday of the general property tax, all forms of property were taxed by states and local governments. ${ }^{5}$ Today, state governments rely on other methods of taxation. For example, California has followed a separation of sources policy since $1933 .{ }^{6}$ Under this policy the state foregoes property tax revenues in favor of other sources of revenue. Since 1933, the local governments in California, however, increasingly have relied on the property tax.

\section{A. The Existing System: Structure and Administration}

The property tax is conditioned on ownership of property and measured by property value. While the tax is imposed on both real and personal property, this Comment will only discuss the real property tax. The real property tax is imposed on the value of land and improvements. Calculation of the tax in California involves a three step process. First, the assessor values all property in the county at the full market value for its highest and best use. Second, a percentage of market value is taken as the assessed value. ${ }^{7}$ In theory, all types of property in California are

4 J. Pickard, Taxation and Land Use in Metropolitan and Urban America 13 (ULI Research Monograph No. 12, 1966).

5 G. Benson, The Amertcan Property Tax: Its History, Admanistration, and ECONOMIC IMTPACT 31-44 (1965).

${ }^{6}$ Riley-Stewart Plan, ch. 63, [1933] Cal. Stats. 3072; Gould, The California Tax System, in CAr. REv. \& TAX. Code 33 (West 1956).

7 In California between 1967 and 1971 property will be assessed at an announced fractional ratio between $20 \%$ and $25 \%$. CAI. REv. \& TAX CodE $\S 401$ (West Supp. 1966). 
assessed at a uniform percentage of market value. ${ }^{8}$ The third step in arriving at the individual tax bill is the imposition of the tax rate on the assessed value. Theoretically the tax rate could be determined by dividing the total assessed value on the county assessment roll by the amount of budgetary expenses which must be offset by property tax revenues; in practice, rate computation is more complex. ${ }^{9}$

The property tax is seldom administered as well as the income and sales taxes. ${ }^{10}$ The need for administrative reform is widely recognized ${ }^{11}$ but seldom acted on unless the legislature is prodded by dramatic outside events. ${ }^{12}$ Current standards of acceptable assessment uniformity are too broad. ${ }^{13}$ Today's conventional standard of "good" assessment is a coeffcient of dispersion from the median assessment ratio of twenty per cent or less. ${ }^{14}$ This means that given a large group of houses with the same

Some states require assessment at full cash value by prohibiting fractional assessment. Switz v. Township of Middleton, 23 N.J. 580, 130 A.2d 15 (1957); Note, Inequality in Property Tax Assessments: New Cures for an Old Ill, 75 HaRv. L. Rev. 1374 (1962).

8 In California, uniformity is constitutionally required. CaI. CoNsr. art. XIII, $\S 1$.

9 Budgetary expenses must first be reduced by the revenues to be raised from nonproperty sources. The total assessed value may or may not include the value of exempt properties. If such exempt properties are assessed, their value nust be deducted fron the total assessed value to arrive at the assessment roll. In addition it should be noted that the total rate is a composite of the rates imposed by special districts within the county. In San Francisco the 1966-1967 rate was $\$ 10.61$ per $\$ 100$ of assessed value-a forty-four cent increase over 1965-1966. This mcrease may be explained by a $\$ 22.3$ million increase in the budget, resulting in a thirty-three cent increase; the remaining eleven cents must be attributed to a higher tax imposed by the Bay Area Rapid Transit District. San Francisco Examiner, Aug. 24, 1966, at 1, col. 5.

10 D. Netzer, Some Alternatives in Property Tax Reform, Nov. 4, 1966 (paper presented at the Tax Institute Symposium, Chicago, III.).

11 See F. Bird, The Generat Property Tax: Findnngs of the 1957 Census of Governarents (1960); U.S. Advisory CoMma'n on Intergovernarentai Retations, The Role of the States IN Strengthentug the Property Tax (1963) [hereinafter cited as Role of the States]; 2 Buread of the Census, U.S. Dep't of Comanerce, Census of Governatents 1962; Carr, Need for Disclosure in Property Tax Proceedings, 40 Cax. ST. B.J. 794 (1965); Carr, Property Tax Assessments-Appeal and Judicial Review, 39 CaI. Sr. B.J. 877 (1964).

12 For example, the Bay Area trials for bribery of Messrs. Wolden and Farragen, then assessors for San Francisco and Alameda Counties respectively, undoubtedly assisted in the passage of Asseunbly Bill 80, which significantly reformed property tax administration in California. Ch. 147, [1966] Cal. Stats., 1st Extr. Sess. Klien \& Platt, Aftermath of Scandal: The Ratio Becomes Rational, 41 CAI. ST. B.J. 662 (1966).

13 California has gone further than most states in this area. Cax. Rev. \& TAx. CODE $\S 1605$ (West Supp. 1966), provides for a $15 \%$ tolerance zone around the State Board of Equalization's countywide assessed value to market value ratios. A showing by a taxpayer that he was assessed above $115 \%$ of the State Board's countywide ratio constitutes prima facie evidence of an inequitable assessment.

14 This standard was adopted by the Census of Governarents 1957. The median assessment ratio is the statistical midpoint in an array of ratios representing the sale prices of real property divided by the assessed values. The coefficient of dispersion is computed by measuring the difference between the median assessment ratio and each individual ratio 
value, the assessor is doing a "good" job if the typical house is assessed at twenty per cent more or less than the median. It takes little imagination to think of the intolerable effects that a twenty per cent margin of error would have in the income tax area. In addition to variation within a single jurisdiction, such as San Francisco, variation also occurs between different taxing jurisdictions, such as the nine Bay Area counties. In attempting to analyze the impact of the property tax on land use, the comparison of different areas is greatly complicated by these variations between different jurisdiction $\mathrm{s}^{15}$ and within the same jurisdiction..$^{16}$

Aside from the problems of interarea variations, there are two other points at which the existing administrative system affects land use planning. First, in California the assessor is isolated from the planning team; the left hand does not know what the right is doing. The role of the assessor as a planner should be more carefully examined. Secondly, the criteria of value used in California assessment are at present solely economic. ${ }^{17}$ The economic definition of value leads the assessor to ignore

in the array. The deviations from the mean are then averaged (total deviations divided by the number of deviations). The average deviation is divided by the median assessment ratio and the result is multiplied by 100 . For an illustration see Census of Governments 1962, supra note 11, at 13. In California medians are determined from a stratified random sample and weighted by an expansion factor for each stratum. See CaLIfornIa Senate Fact Finding Comm. on Revenue and Taxation, Report on Property Taxes and OtHer Locat Revenue and TaXaTron, pt. 9, at 97 (1965).

15 In the Bay Area a $\$ 25,000$ louse will be taxed quite differently depending on its location: San Francisco, $\$ 516.04$; Redwood City, $\$ 523.90$; San Rafael, $\$ 526.98$; Oakland, $\$ 602.64$; Concord, $\$ 728.00$. San Francisco Chromicle and Examiner, Aug. 28, 1966, § 1, at 3, col. 1,5.

10 San Francisco taxes vary so widely they defy comparison. For example, House $A$ built in 1947 for $\$ 12,500$ and now worth $\$ 29,750$, an increase of $138 \%$, experienced a $182 \%$ increase in taxes. Similarly, House $B$ built in 1948 for $\$ 27,000$ has increased $62 \%$ in market value to $\$ 43,500$ (incorrectly reported in newspaper as $93 \%$ ), while taxes increased $80 \%$. Id.

In the Mt. Davidson development on Robin Hood Drive assessments range from $2.5 \%$ to $5.6 \%$. In a typical Sunset District block at Moraga and 27th Avenue assessments are at $5.5 \%$, in the vicinity of 12 th and Anza Street at $6.6 \%$, and in the mansion studded area of Vallejo, Green, Broderick and Divisadero Streets at $14 \%$. Recently, 102 residents of Diamond Heights sought reduction in their assessments claiming they were assessed at 16.7\%. San Francisco Chronicle and Examiner, July 31, 1966, § 1, at 4, col. 1.

In 1960-1962, San Francisco had the lowest median assessment ratio among all Cahfornia counties for all types of property, 15.7, and for residential property, 15.0. This should be compared with the median ratio for fifty-eight counties of 22.1 for all types of property, and 22.3 for residential property. Californa Senate Fact Findivg Conar. REPORT, supra note 14 , at $39-40$.

17 The assessor generally assesses all property at its "highest and best use" (i.e. that use which will realize the greatest profit or rate of return). CALIFornta STate BoARd or EQUATIZATION, AsSESSOR's HANDBOOK 34-39 (1966). However, the concept of highest and best use is not found in the constitutional or statutory law of California. Comment, 55 CAIIF. L. REv. 273, 285 n.58 (1967). Use of the highest and best use standard apparently developed among assessors without authorization and has been tentatively approved by the courts in Wild Goose Country Club v. Butte County, 60 Cal. App. 339, 212 P. 711 (1922). 
elements of social value. If social values were incorporated into the criteria of value, the highest and best use might be that use which will promote the safest, healthiest, most culturally stimulating and socially secure environment. ${ }^{18}$ Since the assessor looks only to economic value, he is able to assert that he is only following rather than leading the market development of land. ${ }^{19}$ But even this assertion is probably untrue; California assessment practice is not so sophisticated that it can reflect all current market trends with precise certainty. Were this level of sophistication attained, the assessor would still have to formulate his own concept of the community's future land use. The assessor's existing isolation from community planners makes it impossible to compare his informal nebulous plan with the public general plan of the city.

The existing property tax structure and administration are causes of suboptimal land use. Effective solution of many land use problems will be hampered unless the pressures of the property tax are alleviated. The following sections will discuss the pressures and effects of the property tax in the metropolitan area from the central core to the urban fringe.

\section{B. Central City}

The central city of any metropolitan area is usually characterized by a downtown core of retail and office buildings surrounded by a zone of apartments, hotels, parking lots, warehouses and industrial plants. The city skyline-high rise apartments, sumptuous shopping centers, public buildings, plazas and parks-may appear impressive. Behind the facade, however, are blighted residential neighborhoods, a blend of junkyards, rundown small stores, bars and ancient school houses. Since the city is usually older than the suburbs, the costs of maintenance are higher. Costs associated with age include repaving streets, replacing obsolete lighting, and replacing obsolete sewage disposal systems. The problems of minority ghettos and slum areas add to the costs of the city budget. For example,

18 Moffitt, Planning and Assessing Practice, 42 LAND ECON. 371 (1966). Moffitt recommends a balancing of these two definitions of value. This could be accomplished by programing a computer with the following data: all assessment information for every parcel of land, all land uses possible, trends in land use development, community functions, operational characteristics, neighborhood amenities-e.g. view of the Bay-and the community general plan. Using this raw data the assessor arrives at "value" through the use of a "utility quotient," i.e., the market value nnodified by the contribution or detraction for overall utility or socially desirable land usage as established by the general plan. Id. at 377 .

19 Statement by Philip E. Watson, Los Angeles County Assessor, before the Assembly Interim Comn. on Revenue and Taxation, Los Angeles, Cal., July 28, 1966. Mr. Watson disclained responsibility for the fact that elderly pensioners were being forced by high taxes to sell their homes and move out of Mahbu and parts of the West San Fernando Valley. The basis for the disclaimer was his analysis of the rise in market values in adjacent areas and changes in long-range master plan zoning. 
the central city usually has larger public welfare expenses than the suburbs. ${ }^{20}$ The older cities may be plagued by poor fiscal mismanagement, political corruption and waste, and improvident bond issues.

Increasing costs of financing combined with a decreasing tax base as middle class homeowners move to the suburbs ${ }^{21}$ lave created high effective property tax rates in the central cities. ${ }^{22}$ As a result of the decreasing base and the increasing costs, the central city government faces a fiscal dilemma: it must decide either to allow services to decline until they correspond to shrinking resources or to increase the tax rate on the remaining base to keep services constant. Increasing the tax rate produces the high effective rates in the central cities. A survey of effective rates in twentythree of the largest central cities shows that in 1962 the median effective property tax rate for these cities was 2.27 per cent compared with the United States average of 1.4 per cent. ${ }^{23}$

In a recent study of tax rate variations in northeastern New Jersey, one commentator found that the high rates tend to be concentrated in the

20 In recent years the fifteen largest New Jersey cities with about one-fifth of the state's real property tax base have accounted for $50 \%$ or more of all municipal expenditures for health and welfare. M. Beck, Property TAXation and Urban LaNd Use in Northeastern New Jersex 42 (ULI Research Monograph No. 7, 1963).

21 Beck breaks the study area into the following categories: Cores $A$ and $B$, Inner Rings $A \& B$, and the Outer Ring. Core $A$ contains twenty-two numicipahities including: Newark, Jersey City, Hoboken, Weehawken and Passaic. Core $B$ contains forty-eight inunicipalities including: South Orange, Hackensack, East Rutherford, Teterboro, Dover, Linden and Nutley. The per capita value of real property in the core areas is less than one-half that in the outer ring. Property values increased with distance from the core, and the growth rate in the core was less than one-half that of the inner ring and only one-third that of the outer ring. Id. at 23 .

22 This statement assumes that the city governments decide to maintain services at a constant level rather than reducing services as the tax base decreases and expenses rise. The rate of property tax will vary depending on the cities' dependence on property taxes. Central cities with a low (under $40 \%$ ) dependence on property taxes will generally have lower tax rates: e.g. Washington (1.17\%), Seattle (1.16\%), Philadelphia (2.64\%), Cincinnati $(1.56 \%)$ and Saint Louis (1.46\%). Central cities with a high (over 58\%) dependence on the property tax generally have higher rates: e.g. Detroit $(3.04 \%)$, Newark $(4.83 \%)$, and Boston $(5.89 \%)$. Revenue raised by the property tax in San Francisco was $50.4 \%$ of budgetary needs. In Los Angeles it was 52.3\%. J. Pickard, TAXation and LAND Use, supra note 4 , at 38 .

${ }^{23}$ Id. See also Gaffney, Property Taxes and the Frequency of Urban Renewal, in Nationat Tax Ass's, Proceednas of the 57th ANnuat. Conference 272 (1964). Gaffney points out the consequences of a $3 \%$ property tax on construction. He uses a comparison to an excise levied once at the time of construction. He uses a 60-year useful hife. An annual payment of $\$ 1$ per year for 60 years has a present value (discounting at $5 \%$ ) of $\$ 19$ using standard annuity tables. Thus a $1 \%$ rate (\$1 per $\$ 100)$ would amount to a $19 \%$ initial excise. At a $3 \%$ rate this would be equivalent to an initial $57 \%$ lump sum excise. It takes little imagination to visualize the impact on new construction of such high rates as Boston's $5.89 \%$, or Jersey City's $5.85 \%$. It is in this context that the 2.27 average large city rate as compared with the national average of $1.4 \%$ becomes meaningful. 
older core communities while the low rates were most common near the periphery. ${ }^{24}$

Massachusetts, hike New Jersey, is a high property tax rate state. ${ }^{25}$ The Boston Standard Metropolitan Statistical Area (S.M.S.A.) contains 50.3 per cent of the total state population. It has an average effective property tax rate of 3.31 per cent. The fact that the Boston core has exhibited unusual stagnation in new construction is in part caused by its singularly high level of property taxation. ${ }^{26}$ However, a similar correlation between higl property tax rates and urban density has been found in states with lower effective property tax rates. ${ }^{27}$

${ }^{24} \mathrm{M}$. BEcK, supra note 20 , at 32-34. New Jersey is not a typical state since it had a low personal income tax and no sales tax. Id. at 14. In 1966, New Jersey adopted a 3\% retail sales tax. Sales and Use Tax Act, N.J. Rev. Stat. \& 54:32B-1 (Supp. 1966). Thus New Jersey has a very high dependence on the property tax which accounted for $71.1 \%$ of combimed state and local tax collections in 1960. Per capita property taxes in New Jersey were $\$ 134.10$ which is almost $50 \%$ over the national average of $\$ 91.15$. The study area included 279 inunicipalities in the following nine New Jersey counties: Bergen, Essex, Hudson, Middlesex, Monmouth, Morris, Passaic, Somerset and Union. A positive correlation was found between population density and high effective property tax rates. The study indicated that high tax municipalities were generally populous, densely settled and relatively poor as measured hy per capita property values. Id. passim. The communities found to bave the highest tax rates were: Winfield Township (15.70\%), Hoboken (7.34\%), Shrewsbury Township $(7.01 \%)$, Union City $(6.88 \%)$, Jersey City $(5.85 \%)$, West New York $(5.45 \%)$, and Newark $(4.94 \%)$. These rates should be compared with the median of $2.34 \%$ for the area. Id. at 39.

$25 \mathrm{~J}$. Pickard, Taxation and LAND Use, supra note 4, at 21 . In the proportion of state and local revenue derived from property tax Massachusetts with $58.49 \%$ ranked fourth behind New Jersey's $71.1 \%$. However, Massachusetts' $\$ 137.24$ surpassed New Jersey's $\$ 134.10$ to lead all states in property tax revenue per capita. J. Picrard, Changrivg Urban LAND Uses, supra note 3, at 48. It may be instructive to compare the Boston and Newark areas with two Califormia cities, San Francisco and Los Angeles. The following represents the property tax as a percentage of all taxes revenues: Los Angeles, 84.6\%; San Francisco, $85.6 \%$; Newark, $89.9 \%$; and Boston, $98.1 \%$. The property tax rates per $\$ 100$ of assessed value are reinarkably similar: Los Angeles, $\$ 8.36$; San Francisco, $\$ 9.39$; Boston, $\$ 9.98$; and Newark, $\$ 10.74$. However, this assessed value figure must be modified by the ratio of assessed to market value to determine the rate per $\$ 100$ of market value. Those ratios are as follows: San Francisco, 24.2\%; Los Angeles, 24.6\%; Boston, 60\%; and Newark, $44.97 \%$. Thus, while the California cities assess around $25 \%$, the Eastern cities are assessing at $40 \%$ to $60 \%$. Therefore the effective rates per $\$ 100$ of market value are higher in the eastern cities: Boston, \$5.89; Newark, \$4.83; San Francisco, \$2.27; Los Angeles, \$2.06. Figures are based on Sazama, Equalization of Property Taxes for the Nation's Largest Central Cities, 18 NaT'x TAX J. 151, 154, 156 (1965).

${ }^{26} \mathrm{O}$ the eight highest rate communities in the Boston S.M.S.A., six are old core communities evidencing population density, low resources, age, and low housing quality. These six older cities include: Chelsea, Boston, Cambridge, Somerville, Revere and Malden. Revere and Malden are the most residential of the core cities. The two newer high rate communities include: Hull-a high density south shore town, and Middleton-a new tract on the urban fringe. J. Pickard, Crangming URban Land Uses, supra note 3, at 48.

27 In Milwaukee County, Wisconsin, the city of Milwaukee and the one suburb evidencing the lowest resources per resident had the higlest property tax rates. Id. at 56 . In the Virginia suburbs of Washington, D.C., a recent study indicated that true property 
Indirect evidence that high property tax rates influence land use in the central cities may be found in the fact that numerous cities have entered into special agreements to provide tax incentives for new construction. ${ }^{28}$ This shows that high property taxes discourage construction in the central city.

The erosion of the central city tax base which itself creates higher tax rates may be exacerbated in turn by the increasing rates. As taxes in the central city become higher than in surrounding areas, private investment decisions will be influenced. Owners of rental or commercial property will balk at a tax rate which takes fifteen to thirty per cent of their gross rentals. ${ }^{29}$ Relatively poor parking in the central city results in a decline in the retailer's share of the market as shoppers prefer the more convenient neighborhood shopping center. These economic factors may lead to a declining market value in the central city. Tlis decline will be aggrevated by the usual "assessment lag." The assessment lag is the period of time before the assessor recognizes and follows land value trends. The length of time before assessment changes reflect actual market changes varies with the method of assessment. If sales of comparable properties are used to determine land values, there must be a sufficient number of sales; unfortunately, sales occur infrequently in the commercial and industrial sectors of the central city. A different time lag will result if appraisal is conducted by the "hot spot," or cyclical methods. Rapid increases in value will readily appear under the "hot spot" approach which reassesses each year those areas showing the greatest sales activity. However, this approach would not satisfactorily show stagnation and downward trends in the central city, for suclr trends produce little sales activity. The cyclical approach involves reassessing sections of the total area each year. The lag would depend on the length of the cycle. In Califorma, countywide cycles vary from one year in Santa Clara and Mariposa Counties to eight years in Merced County and ten years in Tulare County. The Bay Area counties average about five years per cycle. ${ }^{30}$ The effect

tax rates tend to be highest in the most urbanized areas and lowest in the suburban fringe areas. J. Pickard, Taxatron and LAND Use, supre note 4, at 17.

28 The incentive programs used in Kansas City, Milwaukee, and Boston will be discussed below. See notes 65-69 infra and accompanying text.

29 This study indicated the real estate taxes as a percent of gross income for apartments, office buildings and hoth types of structures. In the category of apartments the rates were as follows: Jersey City, 28\%; Newark, 24\%; Boston, 23\%; Jacksonville, 15\%. In the office category the rates were: Des Moines, 26\%; Minneapolis, 23\%; Dallas, 19\%; Providence, 19\%; San Francisco, 17\%; Fort Worth, 16\%. In the category of apartments and offices combined the rates were: New York, 20\%; Chicago, 18\%; Milwaukee, 18.5\%; Pitsburgh, 17\%; and Los Angeles, 11\%. J. PICKARd, TaXatron and LaNd Use, supra note 4 , at 23 .

30 The cycles are as follows: Alameda, 6 years; Contra Costa, 4-5 years; Marin, 5 years; 
of this assessment lag is adverse to the market; in other words, taxes tend to be too high when the market is weak or falling and too low when values are rising rapidly and the market is strongest. ${ }^{31}$

The property tax also affects residential property in the central city. Although taxes are not a chief factor in slum creation, they may aggravate or accelerate the slum process, and they certainly are a force in the wrong direction. The poor condition of many properties in bliglited areas is a result of many variables: poverty of tenants, absentee ownership of multiple unit properties, long-term neglect of premises, vandalism, and the neigliborhood environment created by concentration of bliglited properties. ${ }^{32}$

In recent years numerous national magazine articles have called attention to the property tax contribution to slum perpetuation. ${ }^{33}$ The general argument is that the slumlord who "waxes fat on human misery" is undertaxed relative to those wlio improve or at least maintain their property, since the property tax is based on both land and improvements. According to this argument, the tax on land has two effects. First, it stimulates more effective use of land by forcing landowners to increase productivity to pay taxes. Second, it depresses land prices, as buyers pay less for highly taxed property than they would if it were less heavily taxed. Thus, tax costs are capitalized into selling prices. The tax on improvements retards new construction and penalizes capital investments by increasing the assessed value. Thus, the argument concludes, the slumlord is actually rewarded by a tax subsidy if he allows his property to deteriorate, since this will decrease the assessed value of the improvement component of his tax bill.

While the above argument is based on general common sense and motivated by a sincere desire to "tax the profits out of slums," its assumptions must be further investigated in the light of empirical data. The tacit assumption is that slum ownership is a profitable short run invest-

San Mateo, 5 years; Napa, 5 years; San Francisco, 4 years; Santa Clara, 1 year; Solano, 2-5 years; Sonoma, 6-7 years. CalIForNIA Assembrly INTERTM Comar. ON REVENUE and Taxation, Taxation of Property iv Caltrornia, A Major Tax Study, pt. 5, at 109 (1964). [Hereinafter cited as A MAJOR TAX StUdY.]

31 The 1965 Butte County Grand Jury, A Special Report on Assessment Practices 16. In commenting on assessment in the downtown business district of Oroville (where it would seem much easier to detect declining market values than in larger cities) the grand jury notes, "Property taxes are very high. Property values have generally declined. In inost cases, assessments have not been lowered." Id.

32 J. Picrard, Taxation and LaNd Use, supra note 4, at 22.

33 Breckenfeld, How to Stop Squandering Urban Renewal Money, House aNd HoMse, July 1959, at 49; Falk, Could Tax Changes Cut Public Housing and Urban Renewal Subsidy?, J. of Housivg, March 1961, at 128; Nagy, Realtors/Housing Keys to our Economic Life, Apartarent J., Nov. 1965, at 6. 
ment. This assumption is questionable. One commentator has found that bhighted areas in Newark, New Jersey are taxed at twenty-one per cent of gross property income. Typical net returns were found to be around ten per cent, which is not unduly high for this type of investment. ${ }^{34}$ This study further found a correlation between maintenance and ownership. While resident small property owners have better maintenance than large commercial slum operators, increased taxes fall most heavily on the small owner who has not taken taxes into account in his bookkeeping and adjusted current rent levels.

Justifiable criticism of slumlords for failing to maintain their property should not overlook the way in which these property owners are limited by the structures they own. They face the decision between maintaining the property as a slum, selling the property, or demolishing the structure and replacing it with a more modern one..$^{35}$ Many owners may lack the resources required for destruction and replacement. Most owners would probably maintain the property hoping to sell it in the future to a renewal agency at an inflated price. Another factor is the feasibility of expecting one slum owner to improve his property without assurance that others in the neighborhood would follow suit.

The conventional "tax slums to death" argument has on analysis proven to be somewhat less than the panacea claimed by its advocates. One basic weakness in the argument is the lack of supporting empirical data. The argument assumes that as buildings deteriorate the owner receive tax benefits, this should be reflected by a positive correlation bein the ratio of building values to land values. ${ }^{36}$ If it is true that slums receive tax benefits, this should be reflected by a positive correlation between building-land ratios and blight. However, two recent studies of taxation and bhight failed to establish any relation between building-land ratios and blight. ${ }^{37}$

\footnotetext{
$34 \mathrm{~J}$. PICKard, TAXation AND LAND USE, suppra note 4, at 22 (tentative findings of a ULI research study by G. Sternlieb of Rutgers University School of Business).

$35 \mathrm{~J}$. HEIrBRUN, supra note 2, at 54-59. Professor Heilbrun likens the slunilord to a scapegoat who lives off the slums but has not caused them. Poor housing is essentially the product of poverty. Progress in the eradication of poverty has been and will continue to be quite slow. This fact should encourage investigation of the impact of property taxes on housing standards with a view to tax reforms which would speed our progress.

36 If the conventional argunent is true, the value of buildings should decrease in proportion to the stage of decay. For example: Good Condition: Building (B) $\$ 10,000+$ Land (L) $\$ 2,000=\$ 12,000$; Beginning Blight: (B) $\$ 8,500+$ (L) $\$ 2,000=\$ 10,500$; Decayed: (B) $\$ 5,000+$ (L) $\$ 2,000=\$ 7,000$.

37 Citizens Housing and Planning Council of New York, Tax Policies and Urban Renewal, May 1960, at 7-8; Dayton, Obio Tax Study Advisory Committee, Taxation and Urban Blight, March 1962, at 5-7. These studies may only indicate that the assessor devalues both building and land in the same proportion. Thus if property worth $\$ 12,000$ ( (B) $\$ 10,000+$ (L) $\$ 2,000$ ) declined to $\$ 6,000$ it would be valued (B) $\$ 5,000+$ (L) $\$ 1,000$.
} 
A second basic weakness in the argument is the failure to follow the tax on slums to its logical conclusion. Increased taxes on slumlords will be passed on to the tenants through increased rents. As rents increase, either more people will be forced to live in one room, or low income families will be forced to look for new low cost housing in older suburbs.

The central cities' efforts at urban renewal may also be affected by the property tax system. One writer urges that the basic cause of blight is that land for redevelopment cannot be purchased at true market prices. ${ }^{38}$ Inflated prices paid for slum land by redevelopment agencies result in windfall profits to slum owners. ${ }^{39}$ Redevelopment is often "sold" politically by arguing through cost-benefit analysis ${ }^{40}$ that it is a "costless" activity; in other words, the newly constructed project will add more to the tax base than the loss plus city costs. ${ }^{41}$ This approach seldom considers the fact that the redevelopment project will cause relocation of low income owners and draw in a new class of people. This looks hike the exportation of high-cost citizens in an attempt to attract low-cost, highbase citizens from the suburbs. ${ }^{42}$ Perhaps redevelopment without a planned relocation of the present low income owners amounts to little more than exporting slums to middle aged and older suburbs.

\section{Suburbs}

Suburban areas represent a fiscal grey area between the relative overassessment and high tax rates of the central city and the relative underassessment and low tax rates in rural fringe areas. Suburbs are also char-

38 Walker, Property Tax Expedients in Urban Renewal, in Nationad TAx Ass'N, Proceednags of THe 53Rd ANNUAL Conference 44-46 (1960). She argues that the high prices result in blight rings surrounding the congested downtown area. These lands are held off the market by owners based on false expectations of market value. These false expectations are bolstered by the following six factors: (1) officials' optimistic statements and predictions of growth when the city is in fact stagnant or declining; (2) Census Bureau releases about growth which do not sufficiently indicate that the growth is in the suburbs rather than the central city; (3) federal government purchases of land at inflated prices while absorbing losses; (this attempt to bail out a few owners only serves to entrench the remaining owners) ; (4) unrealistic zoning; (5) failure to enforce building code standards; and (6) lack of sufficiently precise studies showing the artificiality of the land shortage and resultant inflation of land prices.

39 Symposium, The Great Urban Tax Tangle, ForTune, Mar. 1965, at 106.

40 The use and misuse of cost-benefit analysis to determine which projects to select for redevelopment is beyond the scope of this Comment. For a discussion of this subject see Bloom, Fiscal Productivity and the Pure Theory of Urban Renewal, 38 LAND EcoN. 134 (1962).

11 See Testimony of $M$. Justin Herman, Executive Director of the San Francisco Redevelopment Agency Before the Assembly Comm. on Revenue and Taxation, Dec. 16, 1963, San Francisco, in A MaJor TAX Study, supra note 30 , at 344 .

42 The dichotomy between low-base, high-cost taxpayers and high-base, low-cost taxpayers is found in cost-benefit studies conducted by various local agencies. See text accompanying notes $47-48$ infra. 
acterized by governmental fragmentation and a wide variance in financial resources between different communities. In addition, there is diversity in land use patterns at various stages of development throughout areas of suburban sprawl. These land use patterns may be classified as follows: middle aged suburbs, new residential areas, rapidly growing tracts, and tax shelters such as industrial enclaves and communities composed mainly of large estates. ${ }^{43}$

The typical middle aged suburb is composed of property developed forty years ago in the 1920's. They usually are well-balanced with onefifth to one-third of the tax base composed of commercial and industrial property and endowed with reasonably good fiscal management. School enrollment is fairly stable or declining as the child population moves to newer suburban tracts and the older children graduate from high school. At present, tax rates are moderate.

In the foreseeable future most middle aged suburbs will face serious problems. Central city redevelopment and relocation may create increasing demand for low cost housing in the older suburbs. As the property becomes older, the tax base becomes weaker and the rates become higher. The higher rates will discourage the new construction necessary for rejuvenation of the weakened base. As these middle aged suburbs become old age suburbs, they may find they have all the disadvantages of the central city without its advantages. If this in fact occurs, a need for a new suburban redevelopment program is indicated.

As an alternative, the middle aged suburbs may enter into the competition to attract high tax base properties. Since middle aged suburbs are usually in closer proximity to the central city, there may be demand for high-rise, high-rent housing from single persons who like to be close to the city. Many older couples will prefer to move into luxury apartments in the suburban area where they raised their children and have established social contacts. Given the increasing life expectancy of Americans, the number of older couples entering the apartment market will inevitably increase. A study of high rent apartments in the Philadelphia suburbs reveals that less than six per cent of this type of housing is occupied by households with children. ${ }^{44}$

This study also indicated that suburban high-rise apartments exceed all other land uses in revenue production per acre. ${ }^{45}$ Thus it may be concluded that high-rise apartments offer a possible means to supplement revenue losses associated with the aging process by providing high revenue at relatively low service costs.

43 J. Pickard, Taxatton and Land Use, supra note 4, at 37. See also Appendix, infra,

44 Melamed, High-Rent Apartments in the Suburbs, URBAN LAND, Oct. 1961, at 1, 3.

45 Id. at 5. Professional uses are $\$ 97,400$ per acre; industrial uses, $\$ 91,700$ per acre; shopping centers, $\$ 110,000$ per acre; high-rent and high-rise apartments, $\$ 259,500$ per acre. 
The new suburban community is troubled by the problems of growth, particularly the financing of public school construction and equipment. ${ }^{46}$ The property tax often rises rapidly from a rather low starting point to a moderate level. As the rate continues increasing rapidly to meet rising public demands for services, the small suburban governments inevitably compete for new high-base taxpayers such as shopping centers, light industry, and researcli and development facilities.

The concern of new residential communities for the fiscal cost of alternative types of land use lias led to numerous cost-benefit studies. ${ }^{47}$ These studies lack sophistication and analytic precision in allocating costs to various land uses. ${ }^{48}$ Their findings may be generalized as follows: (1) a net revenue gain-gross revenue produced by a property less the governmental cost attributable to that property-is derived from vacant land, industrial uses, shopping centers and ligh-rise apartments, (2) a net revenue loss is derived from single family and multifamily residences. ${ }^{49}$

As the tax rates have increased to meet the rapid growth of service costs, local governments have intervened in the market determination of land trends. This phenomenon lias been called "mercantilist zoning." The policy is simple. Eacli community zones to attract ligh property base taxpayers and repel low-base, high-service taxpayers. This fiscal orientation $^{51}$ discourages optimal regional zoning and ignores the suitability of land use. Mercantihist zoning also produces two abnormal land use pat-

46 The typical new suburb will have doubled its population in the last eight years, while its public debt may have increased five times. J. PICKARD, Taxatron AND LAND UsE, supra note 4 , at 25 .

47 F. Clark, Land Use and Coinmumity Taxes, Report No. 1 to the Town Planning Board of Yorktown, New York, Dec. 1958; G. Esser, Are New Residential Areas a Tax Liability? Dec. 1956; Greenwich Connecticut Planning and Zoning Comm'n, Economic Study of Cost of Government Compared with Property Tax Income in Relation to Classified Property Uses, Plan of Development Report No. 3, 1954; W. ISARD AND R. Cotghin, Municipal Costs and Revenues Resulting froma Community Growth (1957); West Hartford, Conn. Dep't of Planning, Land Use and Municipal Finance, Report No. 1 of the Town Development Plan, 1960.

48 Barnes \& Raymond, The Fiscal Approach to Land Use Planning, J. of THE Ax. Inst. of Planners, Spring-Summer 1955, at 71.

49 The results of these studies may vary significantly depending on the assumption used in the study. For example, Clark, supra note 47 , determines that business has a net loss if he assumes school costs are to be allocated to both business and residential property. However, if he assumes school costs are to be allocated only to residential property, business property represents a net gain. Esser, supra note 47 , concluded that single family residences are a net gain by assuming school costs were born by the state, as in North Carolina. One commentator found that small homes constitute a net loss in three Connecticut towns. B. Schaffer, Small Homes and Community Growth (Institute of Public Service, University of Connecticut, Sept. 1954).

50 Netzer, The Property Tax and Alternatives in Urban Development, in 9 Regional Science Assoctation, Papers and Proceedings 193 (1962).

01 For some indications of mercantilist zoning in the Bay Area see Margolis, The Variation of Property Tax Rates Within a Metropolitan Region, 9 NAT'x TAX J. 326 (1956). 
terns. One is the industrial enclave which gives employment to citizens from the neighboring residential communities. It is characterized by a high tax base composed of industrial property and low service costs resulting from a small residential community. ${ }^{62}$ The second abnormal land use pattern is the estate community composed of large residential lots, one-half acre or larger. Such land use is usually the result of low density zoning designed to attract upper income homeowners. Low density and high property values combine to produce low effective property tax rates. ${ }^{53}$ Low density zoning also produces rapid land consumption, increasing suburban sprawl and the economic and social costs associated with such sprawl. Young families with school age children will be forced into areas where estate zoning is not practiced. The resulting concentration of a large number of low-base, high-cost taxpayers will result either in inequitably high tax rates or in a lower standard of public education and other public services. In this atmosphere of competition one community's gain is another's loss.

One administrative nieans of dealing with these tax shelter communities would be to expand the property tax base along county or regional lines and thus equalize the interarea variations in revenue capacity and service costs. California has progressed further in this direction than the more higlily fractionalized New England states. ${ }^{54}$ In California, assessment equalization occurs both on a countywide and a statewide basis. One

52 Evidence of the success of the industrial enclave device in producing lower rates is readily attainable. In the Boston S.M.S.A., with an average effective rate of $3.31 \%$, the town of Everett has a rate of $1.78 \%$. Industrial and public utility property accounts for $60 \%$ of the Everett property tax base. J. Pickard, Changrng Urban Land Uses, supra note 3, at 49-50. In northeastern New Jersey, of the 279 municipalities studied, the lowest effective tax rate $(0.81 \%)$ was found in the Bergen County industrial enclave of Teterboro. M. BEck, supra note 20 , at $60-61$. In New Jersey, with a $1.75 \%$ state income tax, Teterboro provides an ideal tax slelter. It is 1.20 square miles in area witl twenty-two residents and only two school children. In 1960 it had $\$ 1,319,364$ of real property per resident, of which $\$ 1,318,181$ was commercial and industrial property. Id. See also Appendix, infra.

53 Among the lowest effective tax rates in the Boston S.M.S.A. were five towns with high quality residential property, higb per eapita property values, and low proportions of nonresidential development: Dover, Duxbury, Wellesley, Topsfield and Belmont. Of these five, Dover, Duxbury, and Topsfield were also low in population density. J. Pickard, Changeng Urban Land Uses, supra note 3, at 49. In New Jersey, the lowest tax rate commumities were characterized by: (1) low population density, (2) higl property value per capita, and (3) small population. For example, this characteristic applies to Bedminister, Plainsboro, Alpine, and Harding. M. BEcr, supra note 20, at 33-34. Similar examples may be found in New York (Bronxville and Scarsdale) and in California (Beverly Hills and Hillsboro).

54 Fragmentation is most characteristic in New England, New York, New Jerscy and Pennsylvania. In New Jersey nine counties lave 279 local taxing jurisdictions-cities, villages, boroughs, and townships. In the 212 Standard Metropolitan Statistical Areas (S.M.S.A.) mentioned in the CENSUS of Governmants 1962, supra note 11, there were 18,442 local taxing units. 
commentator has concluded that governmental multiplicity is inherently incompatible with the property tax. ${ }^{55}$

\section{Urban Fringe}

There is a certain amount of inconsistency in the claims relating to the impact of the property tax on the urban-rural fringe. The farmers claim that they are in effect being taxed out of farming. ${ }^{56}$ The argument runs that developers interested in cheap land for subdivision purchase rural farmland near urban centers. As a result of the urban development, the assessed value of farmland is increased by the local assessor to reflect its value as potential residential land. The higher tax rates may well exceed the land's net incoine as farmland, forcing the farmer to sell his land to meet the tax burdens. ${ }^{57}$ According to this argument the farmer is being overtaxed.

However, rural land is usually underassessed relative to the central city and adjacent suburban areas. The assessment lag is more pronounced where the land values are rapidly changing and where the assessor may well be a part-time official without professional training. Also, some argue that the farmer is not overtaxed, since he may take some solace in the large net profit he will realize on sale of his land at capital gains rates. The property tax is thus said to encourage speculation by underassessment, thereby creating artificial inflation in land prices. ${ }^{58}$ Perlaps

55 L. Stiles, Some Possibilities for Meeting Property Tax Problems Arising from Multiplicity of Governmental Units, Nov. 4, 1966 (paper presented at the Tax Institute Symposium, Chicago, Ill.). See also a proposal made by Lorned Cook cited in Wolfe, Taxation and Development, in Planning 1962, at 114 (selected papers from the Nat'1 Planning Conference of the American Soc'y of Planning Officials), recommending that local communities tax only residential properties and that commercial and industrial property be taxed on a metropolitan basis with proceeds reallocated to local commumities. It is argued that this approach would reduce inter-city competition for industry.

50 Stocker, Taring Farmland in the Urban Fringe, TAx Polrcx, Dec. 1963, at 3-5.

57 An additional argument in favor of reducing the tax burden on the farmer is that this would tend to conserve open space lands. A recent amendment to the Califorma constitution adding a new article XXVIII, popularly known as the Breathing Space Amendment, was passed in the California general election in November 1966. One local assessor has charged that this amendment creates a laven for speculators. Statement by Dr. Irene Hickman, Sacramento County Assessor, at a California Open Space Conference, Umiversity of California at Davis, April 14, 1967. A second conservation argument may be inade in terms of preserving top grade agricultural soils or unique farm lands suitable to specialized crops like wine lands in Napa, Livermore, or San Jose, or artichoke land near Santa Cruz and Castroville. See Doerr \& Sullivan, Property Tax and Land Use, in A MaJoR Tax STudy, supra note 30, at 202, 206-09.

58 The documentation for this point of view is as follows: (1) Farms were assessed at $20.2 \%$ of inarket value in 1957 in comparison with $22.7 \%$ for vacant lands, $31.5 \%$ for nonfarm homes and $40.8 \%$ for business properties. (2) In New York, Westchester County assessments rose $10 \%$ while land prices doubled and tripled. (3) Outside Salt Lake City a bidder offered $\$ 7,000$ per acre for property assessed at $\$ 300$ per acre. (4) In Contra Costa 
the problems of speculation and confiscatory taxation of farmland are mutually related. If the tax system is changed to aid the farmer by lower assessment, the speculator also benefits. If, on the other hand, speculative profits are taxed, the farmer interested only in farming is hurt. This may occur unless some adequate means for distinguishing the farmer from the speculator can be devised.

\section{E. Summary}

The existing interrelation of property taxation and land use patterns in the central city, suburbs, and the urban fringe has produced many suboptimal effects. In the central city high rates slow new construction, and the assessment lag results from the assessor's failure to recognize such losses as rapidly as they occur. The tax on improvements discourages remodeling and replacement, thus favoring decay and lax maintenance. The suburbs are broken into fragmented governments frantically engaged in an internecine war to attract high base properties through mercantilist zoning. As the distance increases from the central city, the suburb imperceptibly shades into the urban-rural fringe. With the relentless march of suburban sprawl, the property tax is beginning to be felt by the farmers. The uneasy coexistence between the farmer and the speculator has resulted in a joint effort to reduce assessments on farmland. The second part of this Comment will attempt to evaluate some of the fiscal means often suggested to alleviate these problems.

\section{II}

\section{PROPOSED REMEDIES}

Suggested modifications of the present property tax fall generally into two categories: (1) those which would affect the tax base, and (2) those which affect the structure of the tax. Subpart A of this Part will deal with the changes affecting the base which are associated with minor alterations of the existing property tax designed to meet specific problems. Subpart B will suggest some criteria for evaluation of an entire property tax system and will illustrate the use of these criteria by applying them to the existing tax system. Subpart $C$ will use these criteria to evaluate alternatives to the present tax system. ${ }^{59}$

County a farmer sold three one-acre lots for $\$ 10,000$ each while litigating an assessment increase to $\$ 350$ per acre. (5) In San Francisco a lot on Telegraph Hill assessed at $\$ 3,800$ sold for $\$ 60,000$. Today's Taxes Harness the Profit Motive Backwards: They Abet Specullation, but Penalize Development, House AND HoNE, Aug. 1960, at 138.

59 The changes affecting the structure of the tax also alter the tax base. They are classified separately because they are usually suggested as alternatives to the present system. Thus, subpart A will deal with specific exemptions, such as that provided for urban renewal projects by some states. Subpart $\mathrm{C}$ will deal with the exemption of all improvements (site 


\section{A. Changes in the Tax Base}

\section{Specific Exemptions}

The most politically feasible and often suggested change in the tax base is the use of exemptions. If a particular activity produces results deemed socially desirable and is subject to property taxation, there will always be those who advocate that it be exempted from the tax. The number of exemptions from the property tax base has been steadily increasing. ${ }^{60}$ In addition to the "traditional" exemptions for governmenteducational institutions and religious and philanthropic organizations -there has been an upsurge in new exemptions. ${ }^{61}$ Some of these exemptions are directed at slum abatement in the central cities to encourage urban renewal. For example, the legislatures in Massachusetts ${ }^{62}$ and New Jersey $^{63}$ have enacted provisions taxing urban renewal projects on a capitalization of income basis rather than capital property value.

Specific exemptions do not offer a satisfactory long run approach to these problems. This approach is politically favored because it gives a special interest rehef while the loss is spread among all taxpayers. Exemptions erode the tax base thus imcreasing the tax rate for the remaining taxpayers.

\section{Abatement}

Abatement is a method of delaying the arrival at full market value assessment for tax purposes. It is distinguishable from a specific exemption since it usually exempts property in a decreasing percentage over a limited period of time. Some high tax rate cities have offered abatement

value taxation) and taxation based on an income base (gross rental and net rental). One exception to the above classification is that the unearned increment tax on land values will be considered in Subpart $\mathrm{C}$ since it will be used in combination with other taxes discussed in that section.

60 Role OF THE STATES, supra note 11, at 87. In California exempt properties include: publicly owned property, churches, veterans' homes under $\$ 5,000$ assessed value (approx. $\$ 20,000$ market value), colleges, libraries, museums, cemeteries, charitable institutions and hospitals. CaL. Const. art. XIII, §§ 1, 1Y/4, 1I/2, 1a, 1c; CaL. Rev. \& TAX. Code $\$ 214$ (West 1956).

$61 \mathrm{New}$ exemptions have included: homesteads, veterans, widows, orphans, blind, and aged. Walker, Increasing Clamor for Property Tax Exemptions, TAx Portcr, Oct. 1, 1964, at $1,5-10$. The California Legislature has been requested to give property tax rehef to urban renewal projects financed with federal government funds described as 221(d) (3) housing. Proponents claim the assessed value of such property reflects the use of federal funds, and higher taxes force higher rents, defeating the purpose of the project. See Testimony of Alan Maremont Before the Cal. Assembly Interim Comm. on Revenue and Taxation, Los Angeles, July 29, 1966.

62 Massachusetts Urban Redevelopment Corporation Law, Mass. GeN. LAws ANN. ch. 121A, \& 10 (Supp. 1965).

63 N.J. REv. Stat. 55:14E-11 (1964). 
plans to stimulate new construction. ${ }^{64}$ In 1955 , New York City enacted an ordinance which exempted improvements on multiple dwellings for twelve years and allowed amortization of seventy five per cent of the cost over nine years. ${ }^{65}$ In Kansas City taxes for the first ten years are based on the assessed value of the property before improvement; for the next fifteen years the tax is fifty per cent of the after-improvement value; finally after twenty-five years the property will be carried at full value. ${ }^{63}$

Boston has recently made use of two tax incentive devices to encourage redevelopment. In the case of the eight hundred unit Beacon Redevelopment Project, the city agreed to lease a seven and one-half acre site which would be acquired and cleared by the local redevelopment agency. The lease insures the city a favorable return while the project developers will be insulated from the high Boston tax rates since the city owns the land. ${ }^{67}$

A particularly original approach has been taken in the tax treatment of the new Boston Prudential Center Project. ${ }^{68}$ While the project was still in the planning stage, it became apparent that construction would not be economically feasible at the existing high tax rates. ${ }^{60}$ After numerous conferences the city and Prudential worked out a preferential tax agreement. The constitutionality of this agreement under state's uniformity

${ }^{64}$ Tax Tricks Designed to Do in Slums, 16 J. of Housing, 232 (1959).

65 Id. at 232-33. The New York tax abatement plan was designed to aid landlords in the installation of central heating, hot water, etc. The New York experience proved unsatisfactory since some operators used the incentive to extensively remodel and raise rents thus outpricing former tenants. $I d$.

66 Id. at 233-34. Milwaukee utilizes an assessment freeze for seven years similar to the Kansas City approach. The plan seems to be working fairly well. J. Pickard, Taxation AND LAND USE, supra note 4, at 24.

67 Tax Tricks, supra note 64 , at 234 . Beacon will lease the land for twenty years at an annual fee including: $\$ 24,000$ ground rent, an annual excise of $\$ 10$ per $\$ 1,000$ of assessed value, and five per cent of gross income. The total amount must be at least equal to the present tax income of the land to the city- $\$ 50,000$. It is estimated that this return should allow the city to retire its bond within twenty years. $I d$.

${ }^{68}$ The project site is $31 \mathrm{I} / 2$ acres cut by the main tracks of the Boston and Albany Railroad Back Bay Yard and a six lane turnpike. Prudential proposed to build a plaza over the entire property sufficiently higb to provide legal clearance for the railroad and turnpike. Above it would be a 1,000 room, 25-story hotel, a 52-story office building, 4 retail shops, and a group of 6 apartments totaling 1,750 units. The buildings would cover only $25 \%$ of the plaza area and the remainder would be landscaped as a park surrounded by a ring road integrated with the city streets to minimize the trafic load. Boston Municipal Research Bureau, Boston Redevelopment Contingent on Tax Agreement, Tax Pourcy, Jan. 1959 , at 3.

69 The estimated cost of the building would be $\$ 100,000,000$. The income capitalization approach produces a $\$ 55,550,000$ value. A gross income of $\$ 15,000,000$ less expenses and maintenance of $\$ 5,000,000$ produces a $\$ 10,000,000$ net income. The net income was capitalized at $18 \%$ (taxes $10 \%$, yield $6 \%$, and depreciation $2 \%$ ). Under these circumstances Pradential found it uneconomical to proceed if the building would be taxed at $6 \%$ or $7 \%$ of actual cost since the estimated return remaining for taxes is less than $6 \%$. Id. 
clause was later settled by the state supreme court. ${ }^{70}$ Under the agreement, assessment is to remain at the present level until construction begins above the plaza portion of the Center; aggregate land and building assessment is fixed at an amount which would produce an increase in total tax of one hundred fifty thousand dollars in the first year, increasing by fifty thousand dollars each year for seven years. After that period the assessment is to be fixed at a total tax of not more than twenty per cent of market value but not less than three million dollars per year.

The exemption and abatement devices detailed above have been used to deal with specific problems in high rate central cities. While they certainly provide incentives for new construction, they also erode the property tax base. ${ }^{71}$ Such expedients for the most part fail to deal with other undesirable effects of taxation on land use. If a tax agreement like the one undertaken in Boston is necessary to accomplish redevelopment, perhaps this indicates that the property tax itself should be reevaluated in the light of its detrimental effects on land use.

A tax abatement or tax freeze has proven effective in encouraging new construction and may well prove a satisfactory short run solution to the lack of new construction. A long run approach would be to completely exempt improvements or to lower rates on improvements.

\section{Classification and Special Assessment}

(a) Central City.-A third approach to changing the tax base is classification combined with special assessment. This approach involves classification of a particular land use and imposition of a tax designed to encourage or discourage that particular use. This approach may be used to deal with the problems of either the central city or the rural fringe. In the central city this approach may take the form of a penalty tax on slumlords. Typical of this approach was the decision by a Cook County, Illinois assessor to increase valuations on slum properties sixty-three per cent in 1960 while increasing the valuation on standard properties only ten per cent. However, this approach seems to assume that a precise dividing lime can be drawn between "slum" and "standard" housing. ${ }^{72}$ Even accepting this assumption, one must face the problem of whether or not each county assessor should make this decision independently or whether

\footnotetext{
70 Dodge v. Prudential Ins. Co., 343 Mass. 375, 179 N.E.2d 234 (1962).

71 Walker, Increasing Clamor for Property Tax Exemptions, TAX PoLICY, Oct. 1, 1964 , at 3.

72 As Heilbrun points out, the concept of the "slum" is subjective. Each observer draws his own picture of minimum standard housing, and whatever falls below the standard is a slum. The distinction between "blighted" communities and "slums" is unclear, as is the precise stage at which a blighted area becomes a slum. J. HemrerUn, REAL Estate TAxEs AND URBAN HoUSING 55 (1966).
} 
it is better left to the legislature. Since some of the most pernicious slum evils are population density and congestion, perhaps the solution would be to impose a nondiscriminatory uniform congestion tax. ${ }^{73}$ However, this suggestion may reflect what already exists, since recent studies show a positive correlation between high tax rates and population density. ${ }^{74}$

(b) Fringe Areas.-The use of classification and preferential assessment has also been urged in the urban-rural fringe areas. The justifications for preferred treatment of farmers are fairness in terms of ability to pay and benefits received and conservation of open space. Under prefential assessment farmland is assessed at its value for agricultural use irrespective of other influences on market value. However, since preferred treatment must be extended only to the farmer, not the speculator, proposals must provide meaningful criteria for distinguishing between farmer and speculator. Various states have reacted differently to meet this difficult problem. ${ }^{75}$

73 Mangiamele, A Positive Approach to Population Distribution: A Case for Reversing the Trends, 42 LAND EcoN. 117 (1966). The congestion tax would in effect be a variation of the penalty $\operatorname{tax}$ on slums. The tax rate would increase with population density. Thus the most densely settled areas would be most expensive. This tax would only be useful if the planners wished to encourage sprawl or wished to establish new peripheral towns around an urban center. The congestion tax does not involve classification between slum and standard housing but it will probably effect densely settled areas which are not in fact slums.

74 M. Beck, supra note 20, at 30; J. Pickard, Changnge Urban Land Uses, sulpra note 3 , at 48 .

75 See Hagman, Open Space Planning and Property Taxation-Some Suggestions, 1964 WIs. L. REv. 628, 658-59. States which have adopted some form of preferential assessment include: Arkansas, Connecticut, Florida, Hawaii, Indiana, Iowa, Maryland, Minnesota, Nevada, New Jersey, Oregon and Wisconsin. Such legislation has been proposed in other states: Illinois, Michigan, Massachusetts, Virginia and Washington. For a partial list of statutory citations see id. See also Councit of State Governadents, Farmzand Assessment Practices in the United States (1966), Californta Assemibly Internar Congantree on Agriculture, Preserving Agriculturat Land in Areas of Urban Growth: A Look at the RECORD (Geyer \& Hanauer ed. 1964). The variations in different state reactions can be illustrated by a brief review of the more significant features of several state statutes.

FLA. StaT. \& 193.11(3) (1965). The state supreme court upheld the constitutionality of the statute in Tyson v. Lanier, 156 So. 2d 833 (Fla. 1963). See Wershaw, Ad Valorem Taxation and its Relationship to Agricultural Land Tax Problems in Florida, 16 U. FLA. L. REv. 521 (1964).

Hawaii has statewide zoning in six use groups: (1) single family and two family residences; (2) three or more family residences, apartments, hotels and resorts; (3) commercial; (4) industrial; (5) agricultural; and (6) conservation. Assessments within a zone are based on the value for the zoned use only. HawaIr Rev. Laws § 128-9(d) (Supp. 1963).

An Indiana statute allows a $20 \%$ deferral for a farm located in a conservation district. The owner may apply for an additional $5 \%$ deferral at his option. If the owner is willing to have his property designated as a future public facility he is entitled to an additional 30\% deferral. IND. Stat. ANN. \$§ 64-711(a)6(b), 64-717 (Supp. 1966).

Nevada's 1961 preferential assessment law, NEv. REv. StaT. §§ 361.313-314 (1965), was similar to the New Jersey law discussed infra except that upon development the owner 
In California, a proposed constitutional amendment providing at local option that land use "exclusively for agricultural purposes" must be assessed on that basis was rejected by the voters in $1962 .{ }^{76}$ The legislature then enacted a plan for preferential assessment which grants preferred treatment to the farmer who will agree by contract to keep land in agricultural use for ten years. ${ }^{77}$ Thus, in California preferential treatment is tied to zoning or private contracts. A recently enacted section of the Revenue and Taxation Code provides that the assessor shall consider the effect of enforceable use restrictions on value. ${ }^{78}$ Use restrictions include both zoning and government contracts. The new section establishes two rebuttable presumptions: (1) that restrictions will not be removed or substantially modified in the predictable future, and (2) that the value of the land will be substantially equal to the value attributable to the legally

was required to pay the difference between full assessment and preferential assessment over the prior five years, rather than two years as under the New Jersey law. This law was declared unconstitutional by the Nevada state supreme court in Boyne v. State ex. rel. Dickerson, 80 Nev. 160, 390 P.2d 225 (1964). The court found that the statute violated the state's umiformity requirement.

Ch. 51, § 23, [1960] N.J. Laws 441. This statute was declared unconstitutional im Switz v. Kingsley, 69 N.J. Super. 27, 173 A.2d 449 (Super. Ct. 1961), aff'd as modified, 37 N.J. 566, 182 A.2d 841 (1962). The legislature then proposed a constitutional amendment which was passed in the November 1963 election. Ch. 48, [1964] N.J. Laws 90. The current statute is The Farmland Assessment Act of 1964, N.J. Star. ANN. \& 54:4-23.1 (Supp. 1966). The New Jersey law gives preferential treatment to land devoted to "agricultural or horticultural use," and is combined with a two year deferral recapture provision which requires the owner to pay back taxes equal to the difference between full tax value and preferential tax value if the land use is changed.

ORE. Rev. Stat. $\$ 308.370$ (1965). The Oregon statute provides for: (1) automatic preferential assessment of farms at agricultural value in designated farm-use zones, and (2) outside such zones a Nevada type law applied, supra. Farm-use zones could be used only for farms, schools, churches, golf courses, parks and necessary public utilities. ORE. Rev. STAT. \$ 215.213 (1965).

76 Proposition 4, Official Ballot of the State of Cahifornia, General Election 1962 (a proposal to add $\S 2.8$ to the CAL. ConsT. art. XIII). The basic arguments against the measure were: (1) there was no assurance that prime agricultural land would remain in agricultural use; (2) the definition of "agricultural purposes" was vague; (3) the bill failed to discriminate between speculators and farmers, thus encouraging speculation; (4) oil interests would be exempted from taxation; (5) leapfrogging of subdivisions would be increased. Catifornia Secretary of State, Proposed Amendments to the Constitution (1962). See also Keith, The Assessors and A.C.A. 4, 30 Appratsar J. 392 (1962). The same arguments point to the basic issues confronting the legislature in implementing the newly enacted constitutional amendment, now article XXVIII, which passed overwhelmingly in the November 1966 general election as Proposition 3.

77 California Land Conservation Act of 1965, CAx. Gov'T Code $\$$ 51200-95 (West 1966). See also Snyder, Toward Land Use Stability Through Contracts, 6 NAT. Resources J. 406 (1966); Snyder, A New Program for Land Use Stabilization: The California Land Conservation Act of 1965, 42 LaNd Econ. 29 (1966); Comment, 55 CaIIF. L. Rev. 273 (1967).

78 CaI. Rev. \& TaX. CoDe $\$ 402.1$ (West Supp. 1966). 
permissible uses. ${ }^{79}$ This system raises problems under the state constitution's uniformity clause. ${ }^{80}$ However, an amendment to the California Constitution passed in 1966 authorizes the legislature to: (1) define open space lands, (2) provide enforceable use restrictions for production of food and fibre, natural resources, recreation and scenic beauty, and (3) estabhsh a basis for assessment. ${ }^{81}$ Under this amendment the way is open for the legislature to implement more fully preferential assessment without the fear that a state court will find a violation of the constitution's uniformity clause.

The approach to preferential assessment in Maryland has been beset with legal obstacles. ${ }^{82}$ In 1960, the State Department of Assessment and Taxation was authorized by statute to establish criteria to determine when land is in fact used for bona fide farming. ${ }^{83}$ Simultaneously, the constitution was amended to allow preferential classification in spite of the state uniformity clause. ${ }^{84}$

In Maryland, preferential treatment has had a negligible effect on farm land in outlying areas which were already assessed at farm value. However, in areas nearest urban centers it resulted in a fifty-three per

79 The statute makes it clear that the presumption can be rebutted. It states that nothing in this statute requires assessment at less than a proportion of full cash value on a capital basis. However, the presumption establishes that use restrictions will substantially equate the value of the land to the values attributable to the legally permissible uses. The legislative intent is stated in the statute: "these sections are necessary to implement the public policy of encouraging and maintaining effective land use planning." Id.

$80 \mathrm{Car}$. Const. art. XIII, $\S 1$. The constitutionality of the Land Conservation Act of 1965 was asserted by the California Attomey General, 47 OP. CAL. ATT'Y GEN. 171 (1966). The constitutional question has never been considered by the courts, however, the passage of proposition 3 in 1966 would seem to render the question moot. For a discussion of the constitutional objections which might have arisen see Comment 55 CAIIF. L. REv. 273, 281 n.44 (1967).

81 Car. Const. art. XXVIII.

82 In 1956 a bill was passed over the governor's veto but was found deficient because it failed to define what was meant by "land used in farming." $\mathrm{Ch} .9, \S 1(17)$, [1956] Md. Laws. In 1957 a new law was passed. Cl. 680, § 1(17)(b), [1957], Md. Laws. However, this law was declared unconstitutional by the Maryland court of appeals. State Tax Commission v. Gales, 222 Md. 543, 161 A.2d 676 (1960). In 1960 article 15 of the Declaration of Rights of the Maryland Constitution was amended and a new bill passed.

83 MD. ANN. Code art 81, \& 19(b) (Supp. 1963). The State Tax Commission issued Regulation 9 to the Assessors in 1960. A partial list of the criteria include: zoning, general character of neigliborhood, use of adjacent property, proximity to metropolitan areas and services, submission of subdivision plan, present and past use of land, domicile of owner, farming experience of owner, participation in government farming programs, productivity of land, crop acreage, number of livestock, amount of fertilizer used, number of crops, amount of last harvest for each crop, amount of feed purchased, and ratio of farm use to other uses. P. House, Preferential Assessment of Farmatind in the Rural-Urban Frivge of MaryLand 9 (ERS-8, 1961).

84 MD. Const. Declaration of Rights art. 15. 
cent average reduction of assessments. ${ }^{85}$ The loss in tax base ranged from one per cent to seven per cent. The Maryland system has proven difficult to administer since there are no guidelines defining the relative importance of each factor in determining "bona fide farm" use. ${ }^{86}$ The standards are so broad that there is widespread feeling among farmers and tax administrators that the principal beneficiaries of Maryland's preferential assessment system are speculators and developers rather than farmers. ${ }^{87}$

Preferential assessment has one glaring weakness from the viewpoint of tax equity; it confers a unilateral benefit on the owner of agricultural property while requiring nothing of him. ${ }^{88}$ Some quid pro quo element may be introduced by the use of enforceable use restrictions or a deferral of taxes. ${ }^{89}$ The deferral plan allows the taxing authority to recoup the difference between the market value and the preferential assessment over a given period of years. A basic difficulty with this plan is to determine a period which is long enough to allow the farmer to convert the land as it is needed for urban development.

Preferential assessment may not be the most appropriate approach to the conservation of open space. Effective preservation of open space may call for stronger governmental action, such as the purchase of development rights from the farmers. ${ }^{90}$ Many tax administrators and land use planners have urged that the proper approach to conservation of open space is through such land use controls as conservation easements. ${ }^{91}$

$85 \mathrm{P}$. House, supra note 83 , at 10.

86 In Supervisor of Assessments v. Alsop, $232 \mathrm{Md}$. 188, 192 A.2d 484 (1965), the court ignored the criteria of bona fide farming suggested by the Department of Assessments and Taxation in Regulation 9, supra note 83, and concluded that the controlling factor is whether the property is actively devoted to farm or agricultural use. Alsop had retired on a 70-acre tract of land and allowed his land to be used by a neighbor free of charge for grazing cattle.

$87 \mathrm{P}$. House, supra note 83 , at 15 .

88 Stocker, How Should We Tax Farmland in the Rural Urban Fringe?, in NatToNar Tax Ass's, Proceedings of the 54 th Annual Conference 463, 469 (1961).

89 P. Hodse, supra note 83 , at 18.

$90 \mathrm{Id}$. at 17-18. House points out two weaknesses in this approach, First, where there is strong suburban pressure, development rights may be almost as expensive as fee purchase. Second, even after separating development rights, there is still the problem of arriving at a true measure of agricultural value. In Cahfornia, enabling legislation permits the use of scenic easements. Car. Gov't Code $§ 6950$ (West 1966).

91 W. Whyte, Securing Open Space for Urban America: Conservation Easearents (ULI Techmical Bull. No. 36, 1959) ; Ciriacy-Wantrup, The "New" Competition for Land and Some Implications for Public Policy, 4 NAT. Resources J. 252, 264-67 (1964); Jordahl, Conservation and Scenic Easements: An Experience Resume, 39 LaND EcoN. 343 (1963) ; Comment, 12 Stan. L. REv. 638 (1960). Development rights or conservation easements are defined as less than fee interests in property. The government inay purchase or condemn an owner's right to develop his property, thus preserving open space for the future, while the owner retains title and the right to continue farming or using it as he has in the 
In fringe areas the best way to conserve open space would appear to be by direct action such as conservation easements, purchase of development rights or compensable regulation. Attempting to deal with the problems of the farm by means of preferential tax treatment only encourages speculation. Deferral of taxes promises at best a minor deterrent to speculation. The most effective way to stop speculation would be to tax the unearned increase in the market value of the property. Short of this, it is doubtful that any changes in the tax base will be effective in discouraging speculation unless some change is made in the capital gains provisions on the sale of land under existing federal income tax legislation.

\section{Developer Tax}

The developer tax is a fee imposed on the development of subdivision property which does not provide for parks and recreational facilities. ${ }^{02}$ It is an extension of the practice of requiring a developer to contribute land for recreational purposes. Under the developer tax the city planning board simply refuses to give final approval to the subdivision plan without recreational facilities unless the developer makes a contribution to a special fund. Often the developer may either contribute land or make a cash payment in heu of a land contribution. Some courts distinguish between forcing the developer to contribute land for recreation and requiring that he pay a fee in the form of a developer tax. These courts usually permit forced contribution while rejecting the developer tax. ${ }^{03}$

Minor alterations in the tax base, such as those discussed above, are not directed at the major causes of suboptimal land use and thus are ineffective to cure inequality and misallocation. A complete reexamination of the existing property tax system is necessary.

\section{B. Criteria of Neutrality and Their Application to the Existing Tax ${ }^{04}$}

To deal effectively with the problems caused by the interrelation of the property tax and land use, it is necessary to establish criteria to eval-

past. If action is taken before urban pressures have developed, the cost of development rights may be significantly lower than outright purchase. Weissburg, Legal Alternatives to Police Power: Condemnation and Purchase, Development Rights, Gifts, in OpEN SPACE AND THE LAW 41 (F. Herring ed. 1965).

02 Walker, Land Use and Local Finance, TAX PoLIcx, July-Aug.-Sept. 1962, at 36.

03 Compare id. at 37 (courts support forced contribution), with Kelber v. City of Upland, 155 Cal. App. 2d 631, 318 P.2d 561 (1957), and Gulest Ass'n Inc. v. Town of Newburgh, 25 Misc. 2d 1004, 209 N.Y.S.2d 729 (Sup. Ct. 1960), and Haugen v. Gleason, 226 Ore. 99, 359 P.2d 108 (1961) (courts reject developer tax).

84 This section and subpart $C$ infra are based primarily on the analysis of J. HendRON, Reat Estate Taxes and Urban Housing (1966), and D. Netzer, Economics of tile PropERTY TAX (1966). 
uate the land use neutrality of a particular property tax system. Neutrality should be used as a norm for purposes of comparing tax systems; the property tax system should not affect land use decisions. Any deviation from the norm should constitute a purposive decision by the legislature to deal with the basic causes of suboptimal land use.

To evaluate the effects of a particular tax by a standard of neutrality, it is necessary to provide the following criteria by which neutrality can be measured: (1) effect of the tax on new construction, quality of operation, replacement and remodeling, (2) effect on resources allocation, (3) equity of the tax, (4) adequacy of tax yield, (5) stability of yield during economic fluctuations, and (6) administrative feasibility.

The first criterion relates to the effect of the tax on housing construction, operation, remodeling and replacement. Remodeling is defined as changing the layout of interior space or adding equipment to that already installed. This is to be distinguished from replacement which neither adds to nor subtracts from the given inventory of assets. Quality of operation is a function of variable operating costs for tenant services-doorman, full time superintendent, free washing and drying machines. Rents will increase with services offered up to the optimum level of quality of operation. Beyond this level, each dollar spent to increase quality of operation will bring a declining increase in rent.

The second criterion, resource allocation, is concerned with the effects on land use and the existing stock of housing. The effects of the existing tax on land use in a metropolitan area has been discussed in Part I. At this point the effect of the existing tax on housing will be explored. The primary concern in housing resource allocation is whether or not the tax encourages boarding up the house in depression. This result would follow if occupied improvements were taxed and vacant improvements were not. If housing supply is fixed, in the short run sucl a tax will vary with respect to occupancy. As occupancy declines in times of deflation, eacli occupant's share of the tax burden increases, causing a further decline in occupancy; eventually, the owner is forced to board up the housing.

The third criterion, equity, inay be considered from three viewpoints. From one point of view, equity should look to the justification for imposing the tax in terms of ability to pay or benefits received. Another point of view would evaluate the equity of a tax in terms of its progressive or regressive redistributive effect. Finally, equity may look to whether the tax treats similarly situated taxpayers the same or differently. This final point of view seems most appropriate to the evaluation of a property tax system for purposes of this Comment.

The fourth criterion, adequacy of yield, is concerned with the problem of whether or not the new alternative system will produce a yield sufficient 
to offset the loss of revenue caused by the change. The standard of revenue adequacy is assumed to be the current yield of the existing property tax.

Stability of yield refers to the stability of the tax base during economic fluctuations. Clearly the yield could be held constant by simply increasing the tax rate as the base decreases, thus the critical factor in stability is how price fluctuations affect the tax base.

The final criterion, administrative feasibility, again posits the existing system as the norm and then attempts to determine whether the suggested change would make the administration of the tax more difficult.

To illustrate the application of the criteria of neutrality, it may be helpful to apply them to the existing tax system. Since the existing system constitutes the norm for evaluating adequacy of yield (criterion number four) and administraitve feasibility (criterion number six), those factors will not enter into the analysis.

With regard to new construction, the existing tax on improvements in the short run inhibits investment in housing unless the tax can be shifted forward to the tenants. The tax is shifted either by a decrease in housing supply (because new housing is not built fast enough to replace old housing) or an increase in demand (because of income or population increases). To analyze this shifting process three possible situations will be assumed: (1) constant population and income with decreasing housing supply, (2) constant population, increasing income and decreasing supply, and (3) increasing population, constant income and decreasing supply.

Under the first assumption, given a low elasticity of demand for housing space, a decrease in housing supply will result in a relatively large rise in rent. As rents rise, the tenant's real income will fall. Decreased income will have a significant effect on demand for housing quality. Thus, demand for good condition of structures will diminish. The net result will be that buildings are maintained at a lower structural quality and that the optimum quality of operation will be lower. ${ }^{05}$ This effect may be partially offset if a portion of the tax increase is shifted back to landowners in the form of reduced site rent.

Under the second assumption, there will be an increase in demand for space and quality due to increasing income, but new construction and remodeling will still be in abeyance since we assumed decreasing supply. Consequently, the standing stock of housing will be smaller and rents higher, the average quality of buildings will be lower due to lack of new construction, and adaptation of existing housing to changes in demand will be inhibited by the tax disincentive to remodeling. Under the third

$95 \mathrm{~J}$. HenBRUN, supra note 94 , at 93. 
assumption, as housing supply decreases in the face of increasing population, the tenant's real income will be lower. Thus, demand for quality will decrease.

The existing tax on improvements inhibits new construction in the short run before the tax is shifted forward to the tenants. As a result of the shifting process, demand for quality is reduced. The reduction of demand for quality lowers the optimum point of quahty operation and adversely effects replacement and remodeling.

As previously pointed out, the existing tax produces many suboptimal land use patterns. Thus it has a negative effect on land resource allocation, one of the criteria of neutrahity. However, the existing tax applies to both vacant and occupied housing and therefore inust be classed as neutral with regard to housing resource allocation.

The third test is equity. The degree to which the existing system treats similarly situated taxpayers similarly depends on the administration of the tax. In theory, two property owners who both own houses worth twenty-five thousand dollars should be taxed at the same rate. In practice this seldom occurs. Thus, the existing tax system is not neutral from the standpoint of the criteria of equity.

The fifth element of neutrality is stability of yield. The present system tends to be quite stable due to the built-in stabilizer of assessment lag. As noted earlier, values rise and fall more rapidly than assessments. This lag has the effect of restricting the amplitude of fluctuations to some extent.

The criteria of neutrality suggested above are designed to determine the economic neutrabity of an entire tax system rather than simply the neutrality of one particular manifestation of the tax, such as its effects on land use. The existing tax has been examined under the criteria of neutrality and found to be non-neutral in its effect on new construction, quality of operation, replacement, land use resource allocation and equity. It is neutral in building resource allocation, stability of yield and administrative feasibility. The deviations from neutrality in land use allocation are for the most part not intentional deviations, but rather necessary effects of the existing system.

\section{Changes in Tax Structure}

Various changes in the property tax structure have been suggested as alternatives to the existing system. Such proposals include change to a tax measured by rental income, or a tax imposed solely on land values. These alternatives should be evaluated by the criteria of neutrality. Other taxes such as the land value increment tax and user charges are discussed here because of their value as supplements to other taxes. These 
taxes may be useful in attempting an intelligent deviation from neutrality. Thus the criteria of neutrality are not applied to those taxes.

\section{Gross Rental Tax}

The first proposal is a proportional tax on actual gross rent of the site and improvement. It is levied on the gross economic rent of site and improvement combined. Since it applies to actual gross rent rather than assessed gross rent, it would not fall on vacant property. This tax may be visualized as a constant proportional deduction from gross rent along a revenue-cost curve. As taxpayers adjust to this tax in short run, they will reach a new equilibrium by reducing rent more than operating costs. Accepting Heilbrun's theory that rent and cost determine the quality of operation decisions, ${ }^{96}$ it follows that the new optimum operating point results in lower quahity operation. ${ }^{97}$

The gross rental tax also has a detrimental effect on replacement. ${ }^{98}$ The tax reduces marginal rent receipts per dollar of marginal outlay on replacement. Thus the proportional tax has a negative effect on new construction, quality of operation and the rate of replacement.

A tax based on actual gross rentals has undesirable resource allocating effects. Since the tax increase is proportional to rent income, an owner would minimize his taxes by putting land to a noncommercial use. A vacant piece of property would pay no tax. This not only encourages speculation but also encourages boarding up during periods of depression. There are no glaring problems of inequity since this tax operates as an excise on the consumption of real estate services reflected by gross economic rènts. This tax also fares well in terms of adequacy of yield, because whatever taxes are paid under any system of taxing rental housing must ultimately come from gross rentals.

The gross rent tax would not prove unstable over the minor fluctuations in the business cycle but would be less stable than the existing tax during major fluctuations. Recent studies indicate that gross rent is more volatile than assessed value over the business cycle. ${ }^{92}$ This tax has

96 Id. at $15-20$.

97 Id. at 78 .

98 Id. at 90. Optimal replacement expenditures occur when marginal cost equals marginal revenue (gross rents). Since gross rents are being taxed, marginal revenue (MR) will be gross rents (GR) less the tax rate (t) times gross rents. Stated mathematically: $M R=G R(1-t)$. Thus, under a gross rent tax marginal revenue is reduced proportionately as compared with pretax marginal revenue. To reach a new optimum point at which margimal cost equals marginal revenue, the owner will reduce expenses for replacement. Because less is spent on replacement at this new optimal point, it may be said that under the gross rental tax, replacement is suboptimal relative to the pretax optimal point.

99 From 1929 to 1935 in New York assessed values fell 15\% while nationwide gross rentals fell $36 \%$. A second study showed that gross rents rose $36 \%$ (1920-29), fell $40 \%$ 
advantages over the existing system of tax administration. It is more easily administered on rental property. It eliminates the assessment system, thus eliminating assessment lag and associated problems of systematic under or overassessment. However, it also presents numerous administrative difficulties. It requires the imputation of economic income on owner occupied housing. In addition, a self-assessment system may lead to tax evasion and the associated expenses of investigation and detection. If the tax is imposed on the contract cost of rent, variations in landlord services at one contract price would not be considered. Thus true economic rent would not correspond to contract rent. On balance this tax seems to add as many difficulties as it eliminates.

\section{British Rates}

Another alternative tax, the British "rates" system, is similar to the first proposal. The "rates" system is a tax on the net value of occupied real property. The tax base is the rent that could be obtained by renting property less the cost of maintenance and insurance expenses. The net amount is arrived at by using a statutory formula to determine deductions for maintenance and insurance. The tax on a residence would be computed as follows: First, annual rental value is assessed by the central government; then a deduction is taken for annual maintenance and insurance at a specific statutory ratio of the gross value (not actual expenses); finally, the rate is applied at a constant percentage of ratable value ${ }^{100}$ and is paid by the tenant in rental housing rather than the owner. If the property is vacant, no tax is due. If this tax is suddenly imposed on tenants, they will wish to reduce rents by the amount of the tax due. Since this tax may be slifted back to the owner in the sliort run, it may produce detrimental effects on new construction, replacement and quality of operation. The only difference between the effect of "rates" and the gross rental tax is that since the "rates" tax is progressive rather than constant, it will have a stronger effect on high rent housing and a weaker effect on low rent housing. ${ }^{101}$ The rates tax will have the same effects on resource allocation as the gross rental tax above. Thus it favors non-

(1929-35), then rose 43\% (1935-50). During roughly the same periods assessed values rose $127 \%$ (1920-32), fell 19\% (1932-44), and rose 16\% (1944-51). J. HeIrBRUN, supra note 94, at 144-45 \& Appendix B.

100 Although the British rates are applied at a constant percentage, the deduction ratio decreases slightly as annual rent increases giving a somewhat progressive character to the tax. The gross rental tax, on the other hand, does not have a progressive element. J. HEIlBRON, silpra note 94 , at 68 .

101 This and all following conclusions are based on the "theory" of British rates. In practice the ratable value has been established as of June 30,1939 and held constant. This has the effect of making rates a fixed cost with respect to operating outlays and thus negating the effects on new construction, replacement and quality of operation. Id. at n.5. 
commercial uses, speculation and boarding up in periods of depression. The British rates system is a consumption excise like the gross rental tax because it only apphes to services actually consumed. The conclusions about the gross rental tax regarding equity, adequacy of yield and administrative feasibility also apply to the rates system. By its current use in England, the tax demonstrates its administrative feasibility. The "feasibility" involved here, however, is a change from the United States system to the British system. The British tax transplanted to the United States may be less stable than the present system since current gross earning power of property may vary inore than capital value. On the other hand, the British rate system may be more stable than the gross rents system, since it includes assessment mechanisms subject to lag and not fully reflecting the inarket.

\section{Net Income}

A third proposed change in property tax structure calls for a tax on the actual net income from site and improvements. It is distinguishable from the rates tax since deductions are based on actual expenses, except for taxes, paid by the owner. Taxes are excluded to avoid the problems of a tax based on an amount determined by subtracting the tax itself. Assume the tax on profits is at a constant rate and that all property is debt free. ${ }^{102}$ Imposition of a proportional tax on profits does not change the profit maximizing point. This tax will therefore be neutral in its effect on the quality of operation and rate of replacement. However, the tax will pose great problems in determining the net income for owner occupied housmg since net income must be imputed. Imputation will be troublesome due to the lack of sufficient data on rental inarkets. If the imputed rent is not allowed to fluctuate with the business cycle, the tax burden will be great on homeowners during a depression.

The net income tax has different resource allocation effects than the gross rental tax. The net income tax does not apportion the burden between land and improvements in the same ratio as does the gross rental tax. The land portion of the tax base will be identical for both taxes on vacant land since the gross land rent equals net land income. However, the building portion of the tax base will be different under the two taxes. The gross rent approach produces a much larger tax base for buildings than does the net income approach. If we determine to produce a fixed amount of revenue, the gross rental rate will be lower than net income because of the larger tax base for buildings. Thus the gross rental tax takes relatively more building rent and less land rent, while the converse is true with

102 Elimination of debt avoids the problem of deductibility of interest for tax purposes. 
regard to the net income tax. Therefore, the gross rental tax falls more heavily on buildings than the net income tax. This has two effects. First, the tax on buildings is passed on to the tenants with negative effects on new construction. Other things being equal, the gross rental tax discourages new construction more than the net income tax. Secondly, the net income tax has a stronger effect on land and would discourage noncommercial uses and speculation.

The net income tax varies with profits, not occupancy; and has no effect on the boarding up problem. The adequacy of the yield of the net income tax varies over the business cycle. ${ }^{103}$ The tax base is clearly adequate in periods of prosperity or moderate recession. In a major depression a net income base may prove inadequate for two reasons: (1) Net rents would fall below the level of taxes, and (2) loss properties will become so numerous that the rate of the remaining profitable ones would soar to prohibitive levels.

The change to a net income tax would raise a number of administrative problems. First, the problem of a governmental attempt to impute net income on owner occupied property. The local property owner can understand fairly well the concept of market value determined by the price a willing buyer would pay a willing seller. It may be more difficult for him to understand the concept of rental value reduced by actual expenses less taxes. A second problem is the assessor's difficulty in determining deductions to be allowed each owner. Perhaps this problem could be overcome by making the property tax under a net rent system selfassessing. ${ }^{104}$ Under this plan the homeowner would submit a property statement similar to his federal income tax return. However, this program would introduce the problems and expenses of detection and prevention of tax evasion. The imputation of housing income as a basis for taxing owner occupied property would involve either a change to a self-assessed property tax or monumental administrative problems for the assessor.

The first three taxes discussed in this section-gross rental, British "rates", and net income-are each a complete substitute for the present

${ }^{103}$ Net rentals during 1929-1934 declined 55\% nationwide; during the same period gross rental declined $36 \%$. A second study shows the novement of net income before taxes or depreciation in New York: 1929-35, a 47\% decline; 1939-44, a 49\% decline. The conclusion to be drawn from these studies is that real estate net income is highly volatile over the business cycle. J. HeIrBRUN, supra note 94 , at 146 .

104 Goode, Intputed Rent of Owoner Occupied Dwellings under the Income Tax, $15 \mathrm{~J}$. or Fivance 504 (1960). He argues that taxation of imputed income on owner occupied housing is administratively feasible. In addition, he argues for a self-assessed estimation of gross rental value based on (1) original cost, (2) amount of debt inortgage, and (3) assessed value. He also would take a standard rate of return on the owner's equity. He argues that imputed rent would act as a stabilizer since it would remain constant over the business cycle. 
property tax system. They each involve a change from capital value to an income base. It is submitted that the income base would not be economically or administratively feasible if applied to owner occupied housing. However, use of the income base would be feasible in assessing rental housing and business property. Of the three taxes, gross rentals and the British "rates" seem to be the least desirable due to their effects on new construction, quality of operation, replacement, and housing resource allocation. It is submitted that, if applied only to rental housing, the net income approach would be superior.

\section{Land Value Increment}

The land value increment tax is imposed on increases in the value of the land. This may be viewed as a supplementary capital gains tax levied on the gain in value above the owner's basis. ${ }^{105}$ Unlike the tax systems discussed above, the land value increment tax does not offer a complete alternative to the existing system. The justification of this tax is the existence of unearned increments in value. The proponents argue that the provision of services by the community-water, sewer, electricity, roads and schools - are the primary cause of increases in land values. The tax may be imposed amually or only when the property is transferred. One commentator argues that the annual or periodic tax will fall on paper profits, involve administrative difficulties and result in inequities. ${ }^{108}$ Homeowners who pay taxes during inflation but are forced to sell in a depression would be heavily penalized. The land value increment tax therefore should be imposed only when property is transferred by sale, gift or bequest.

The increment tax would tend to produce certain land use clianges. It would curb speculation by reducing the net return from sales. This would make the withholding of land for speculation less profitable. It would also tend to encourage more intensive land use by reducing the profit in speculation. Since it taxes land more heavily than other investments which receive capital gains, it would marginally reduce land prices, encouraging development.

The revenue produced from a land value increment tax levied once at the time of transfer will be inadequate to replace the existing system. ${ }^{107}$

105 The land value increment tax is to be distinguished from site value taxation, for the latter eliminates the capital value of land from the tax base by taxing only land values. A shift to site value would include past increases in value which may have been paid for by new owncrs prior to the change in tax systems. The increment tax, on the other hand, recognizes capital values and deals only with future increments in value, not existing values. See E. Seltaman, Studies in Public Finance 271 (1925).

100 Walker, supra note 92 , at 27 . tion.

${ }^{107}$ If the rate is low, the yield will be small; if it is high, owners will postpone realiza- 
However, this tax may be used as part of a total tax structure. It has advantages if used either to replace special assessments ${ }^{108}$ or to encourage development.

\section{User Charges}

Professor Netzer of New York University argues for a "family of user charges" or benefit taxes which are clearly linked to the nature of public services received. ${ }^{109}$ The revenues from the property tax are used to finance many services not directly related to the property itself, such as schools, welfare and transportation. ${ }^{110}$ The user tax would tax property on the basis of property oriented services, such as police and fire protection, water supply, sewage and refuse removal. User taxes, like land value increment taxes, offer a partial replacement for the existing tax system.

Such a tax system raises serious questions of administrative feasibility. ${ }^{111}$ Some agency would have to coordinate and make decisions as to which services are linked to property and how they should be allocated. The complexity of this classification and allocation would greatly reduce the taxpayer's understanding of the tax system. The "family" of user charges may produce many unwanted "children." Administration of this tax would require a single centralized assessment organization capable of making many decisions on cost and benefit connections. The very complexity of determining the tax base would virtually eliminate the chance of effective appeal, since the local board of supervisors probably

\footnotetext{
108 The special assessment is a halfway house between the property tax and the user charge discussed below. The cost of capital improvements (sewers, streets, subways, etc.) is distributed among property owners based on the physical extent of property used. The increment tax would look to the effects of the improvement on market value when the property is sold. The assessment predicts the future effect of the improvements on property values.

109 D. NETZER, supra note 94, at 214-217.

$110 \mathrm{Id}$. at 214 .

111 See $i d$. at 216 . It is often difficult to isolate precisely those services which benefit property owners in that capacity. For example, fire protection covers real and personal property, yet the latter is not taxed in many states. If the value of fire protection is related to the market value of the property, then why does replacing an obsolescent building with a modern fireproof one, lessening the need for fire protection, result im an increased assessment? Perhaps only that percent of police protection allocable to suppression of arson and vandalism really benefits property, simce real property cannot be stolen. Most police efforts relate to protection of individuals, not property. The following services are probably oriented toward property and taxable as benefits: samitation, sewers, sewage disposal, streets and highways, and water supply. Professor Netzer rehes on Vickrey's allocation. Vickrey, General and Specific Financing of Urban Services, in Public ExPENDITURES Decisions II THE URBAN Comarunity 64-86 (H. Shallar ed. 1963). Vickrey proposes the following allocation methods: (1) water costs on the basis of front footage; (2) fire protection on the basis of either land area or land value exclusive of improvements; (3) utilities, electricity, and mail delivery on the basis of front footage.
} 
would not be able to understand the value determination process. ${ }^{112}$ While not adequate as a replacement of the existing system, user charges may supplement a new tax system, such as the one proposed in this Comment.

\section{Site Value}

In recent years there has been renewed interest in site value taxation. ${ }^{113}$ Pure site value taxation involves a tax solely on the market value of land. It would drastically reduce the tax base by completely exempting improvements. Most modern advocates of site value taxation have toned down the more extravagant claims of their predecessors. ${ }^{114}$ Broadly defined, site value taxation includes any system which taxes land more heavily than improvements.

The economic argument in favor of the tax is that a site value tax operates independently of the value or condition of improvements and thus is constant for all levels of operating outlay and replacement. The tax remains the same whether the land is vacant or the site of a fifty story skyscraper. It would also be neutral with regard to building resource allocation, since it falls equally on occupied and unoccupied buildings. Site value taxation is not neutral in its effect on new construction. It encourages more intensive use of land and discourages speculation by increasing the cost of holding property. It is difficult to evaluate the site value tax in terms of equity. While it appears to treat similarly situated taxpayers similarly, it may discriminate against some taxpayers who use land less intensively, such as farmers, while favoring other taxpayers,

112 The assessment appeals boards of the future, as established by local counties under CAL. Const. art. XIII, § 9.5 (amended by Proposition 12 passed in the November 1966 general election), would, even if they could understand the process of value determination, be forced to spend most of their time explaining the tax bill to the protesting taxpayers.

113 See Falk, Could Tax Changes Cut Public Housing and Urban Renewal Subsidy? J. of Housnrg, March 1961; Symposium, The Great Urban Tax Tangle, Forrone, March 1965; Gaffney, Property Taxes and the Frequency of Urban Renewal, in NaTionaL TAX Ass's, Proceednas of the 57tre ANndaI Conference (1964); Nagy, Realtors/Housing Keys to our Economic Life, Apartument J., Nov. 1965; D. Netzer, Some Alternatives in Property Tax Reform, Nov. 4, 1966 (paper presented at the Tax Institute Symposium, Chicago, Ill.) ; Prentice, Taxes and the Death of Cities, ArcertrecruRAx F., Nov. 1965, at 56; Today's Taxes Harness the Profit Motive Backwards: They Abet Speculation, but Penalize Development, House AND HoME, Aug. 1960, at 137; Walker, Property Tax Expedients in Urban Renewal, im National Tax Ass's, Proceedngs of the 53Rd AnNual Conference (1960); Walker, Taxation and Development, in Planndos 1962102 (selected papers from the Nat'l Planning Conference of the American Soc'y of Planning Officials).

114 Compare authorities cited note 113 supra, with H. GEORGE, Progress AND PoverTY (1879), and Buttenheim, The Relation of Housing to Taxation, 1 Law \& ConTEMr. Prop. 198 (1934). Site value taxation bas been suggested as a panacea for urban land use, a cure for unemployment, a preventative for inflation and a guarantor of perpetual industrial and international peace. D. NETZER, supra note 94, at 197-98. 
such as homeowners. ${ }^{115}$ Site value taxation may be criticized on grounds of inadequate yield, instability over the business cycle and lack of feasible methods of administration.

The most important question for present purposes is the effect site value taxation would have on land use. A recent study of a Vancouver, British Columbia suburb may cast some light on this question. ${ }^{116}$ Having establislied an average ratio of improvements to land, the study then notes that different land uses in the general area have different ratios of improvements to land values. ${ }^{117}$ If the ratio for a particular land use is above the average ratio, taxes will be reduced under a site value system. The lighest ratios were found in new planned subdivisions and residential properties, while the lowest were found in agricultural and slum areas. ${ }^{118}$ Thus site value taxation would encourage suburban sprawl while discouraging agricultural uses.

One economist argues that while the existing tax system reduces the frequency of urban renewal, a sliff to site value taxation would remove the fiscal deterrent to renewal. ${ }^{119} \mathrm{He}$ argues that building taxes are imposed on an erosive base; that is, taxes are higliest when the building is new and then taper off as it ages. Substituting site value taxation would change the erosive base to a nonerosive base because land value should remain constant or increase. This economist urges use of site value taxation, which he asserts would constitute an extension of credit to the builder by the city.

Critics of site value have offered three basic arguments: (1) site value taxation will not have the effects claimed or will produce undesirable side effects; (2) it creates admimistrative problems; and (3) it will not yield sufficient revenue.

115 This would only be true if the improvement to land ratio of homes was higher than the general average. If it were lower, taxes would rise.

116 M. Rawson, Property Taxation and Urban Developarent (ULI Research Monograph No. 4, 1961) (study of the suburb of Burnaby, B.C.).

117 Id. at $17-21$. In Burnaby the total assessed value was $\$ 188,031,725$, while the land value was $\$ 48,359,880$. Id. at 21 . The ratio of total assessed value is thus $3.888: 1$. The average ratios by class were as follows: residential $4.396: 1$; commercial $3.199: 1$; industrial $2.983: 1$; agricultural $1.485: 1$; miscellaneous $3.141: 1$. A low improvement to land ratio may indicate either an undeveloped site or an intensely developed site in a high land value area. Id. at 20 .

118 On the relation of building land ratios and blight compare id., with Citizens Housing and Planning Council of New York, Tax Policies and Urban Renewal, May 1960, and Dayton Ohio Tax Study Advisory Committee, Taxation and Urban Blight, March 1962.

119 Gaffney, supra note 113 passim. While site value would remove the fiscal deterrent to urban renewal, it would also not be neutral in its resource allocative effects. Site value taxation would tax slum dwellings more heavily since they will usually fall below the average commumity ratio of building value to land value. It may be argued that this constitutes indiscriminant stimulation of renewal. 
In a highly imaginative approach to the problem, Professor Hagman of the University of California at Los Angeles outlines some of the difficulties with site value taxation. ${ }^{120}$ Forcing intense use of land may make zoning necessary to limit high building density. ${ }^{121}$ No sale would be possible where the market would not support a use intense enougl to pay the taxes. The tax would not distinguish between desirable low rent housing areas and undesirable slums, thus tending to eliminate both. Under site value it may become necessary to destroy buildings after twenty years because they no longer can demand the large rents needed to support high taxes. The site tax would also tend to eliminate any civic pride in historic architecture, since only contemporary architecture could survive taxes.

When the only sales occurring involve developed land, it may be impossible to separate the value of the land from the value of the land and improvement combined. Another administrative problem is how to value a site with an improvement that would be more valuable without the improvement. Perhaps old buildings should receive an unearned decrement.

Another critic of site value taxation points out that removal of seventyfive per cent of the tax base-improvements-will cause a tremendous increase in tax rates. ${ }^{122} \mathrm{He}$ argues site value taxation will not stop rapid turnover speculators, mentioning that the most rapid increase in land values in Western Canada occurred after site value taxation had been introduced. ${ }^{123}$ Nonspeculators who hold less intensively used land will also be hurt. ${ }^{124}$ Persons who purchase land pay part of the "unearned increment" in the purchase price. Site value taxes them for the same increment. ${ }^{125}$ The proposal will increase tax burdens on farm property and the residences of low income families while reducing the taxes on expensive residential property.

Until recently the only area in the United States imposing a modified

120 Hagman, The Single Tax and Land-Use Planing: Henry George Updated, 12 U.C.L.AL. REv. 762 (1965).

121 High taxes would discourage anything but the most intense uses. Arguably, site value taxation encourages congestion in the central city and forces premature subdivision in fringe areas.

122 Plunkett, Taxation and Development, in PuANnIng 1962, at 96, 97 (selected papers from the Nat'l Planning Conference of the American Soc'y of Planming Officials). Plunkett cites Miss Rawson's figures, indicating that in Burnaby the existing rate of $\$ 18,60$ per $\$ 1,000$ would have to be increased to $\$ 72.30$ per $\$ 1,000$ of site value.

123 British Columbia passed its site value law in 1892. Inflation was rampant from 1909-1913. Comment, 57 YaLE L.J. 219, 234-35 (1947). Site values are taxed in British Columbia, Alberta, Saskatchewan and Manitoba. D. NeTzER sulpra note 94, at 203.

124 See Doerr \& Sullivan, Property Tax and Land Use, in A Major TAX STudy, supra note 30 , at 202 .

125 This should be contrasted with the land value increment tax. See note 105 supra. 
or graded site value tax was Pittsburgh. ${ }^{126}$ The Pittsburgh graded tax is a compromise between the existing system and site value taxation. ${ }^{127}$ As such it can hardly give empirical support to either the advocates or opponents of site value taxation. ${ }^{128}$ The most that can be said for the empirical data on the effects of site value taxation is that it is inconclusive. ${ }^{129}$

A further ground for criticism of site value taxation is revenue inadequacy. One economist has attempted to show that for the nation, excluding the farm sector, the unearned increment (land rent) falls short of the revenue productivity of the present property tax. ${ }^{130}$ If we assume that the revenue productivity of the site value tax is insufficient as a

126 Hawaii has recently adopted a graded tax. In 1965 , only $90 \%$ of the taxable building values could be taxed. This percentage will be lowered by units of $10 \%$ over a minimunl of ten years until $40 \%$ is reached. HAwaI REv. Laws $\$ 129-2$ (Supp. 1963). The experience in Hawaii has not produced sufficient results for evaluation at this time.

127 The graded tax was adopted in 1913 in Pittsburgh providing for a gradual untaxing of improvements to $50 \%$ over 12 years (1914-25). The legislation only apphied to the municipal property tax and not to school and county tax levies. In 1960, this meant that the total tax on improvements was $71 \%$ of the land rather than 50\%. In Pittsburgh between 1913 and 1925 the city property tax rate on land increased $119 \%$, while the rate on improvements increased $10 \%$. Meanwhile, assessed values of land increased only $14 \%$ while assessed value on improvements increased $50 \%$. This indicates that the assessors were reflecting increases in market value by increasing the assessed value of improvements rather than land. J. Pickard, Changrig Urban Land Uses as Affected by Taxation 35 (ULI Research Monograph No. 6, 1962).

128 For a more comprehensive look at the graded tax, see Harrison, Housing Rehabilitation and the Pittsburgh Graded Property Tax, 2 DuQuesne L. Rev. 213 (1964), Williams, The Graded Tax int the Redevelopment of Pittsburgh, 22 Am. J. Econ. \& Soc. 251 (1963), Williams, Pittsburgh's Pioneering in Scientific Taxation II, 21 AMr. J. Econ \& Soc. 209 (1962).

129 Site value taxation is used in Western Canada, South Africa, Australia, and New Zealand. A 1964 field investigation by A. M. Woodruff and L. L. Ecker-Racz of land value taxation in Australia and New Zealand found only a minor social and economic impact They observed hittle difference between commumities which use site value and those which do not. D. NETzER, supra note 94, at 204.

$130 \mathrm{~J}$. HeIrBRUN, supra note 94, at 150-54. His argument is based on the premise that to equal the present tax yield, the ratio of the average rate of interest for capitalization of the land rent (i) over the average effective real property tax rate ( $t$ ) nust exceed the huilding (B) to land (L) ratio. Thus, $\frac{\mathrm{i}}{\mathrm{t}}>\frac{\mathrm{B}}{\mathrm{L}}$ He uses the Goldsmith data. See R. Goldsactr, The Natronal Weatte of the U.S. in the Postwar Pertod (1962). Thus, $\frac{B}{\mathrm{~L}}=4.4: 1$ and $t=1.5 \%$. Heilhrun then estimates the capitalization rate of land rent at $5-6 \%$ since land is a secure asset for long term investment. The resulting ratio is $\frac{i}{t}=\frac{4}{1}$. These figures may not accurately reflect variations in certain geographical areas. For exanuple, in California, Ronald Welch, Assistant Secretary, Real Property Division of the State Board of Equalization, calculates a building-land ratio of $\frac{B}{\mathrm{~L}}=1.35: 1$. D. NETZER, supra note 94, at 211 . 
complete replacement for the existing system, this may only indicate a need to combine site value with some other forms of taxation.

\section{Possible Tax Combinations}

One combination tax program was suggested in 1935 by former Assistant Secretary of the Treasury, Peter Grim. He suggested that land continue to be taxed on the present market value base while improvements be taxed on an earnings or capitalization of income approach. ${ }^{131}$

A second combination approach has been suggested by Professor Netzer. His thinking has progressed through a number of tax combinations. In 1962, he suggested a three-tiered device which combined a tax on buildings based on earnings, a heavy tax on the capital value of land and a capital gains tax on land value increments. ${ }^{132}$ In 1966, he suggested a four-tiered approach: site value at half land rent, land value increment at twenty per cent, user charges and a housing tax at not more than five per cent of housing costs. ${ }^{133}$ The last element was added after a realization that given the present income tax favoring owner occupied housing, his property tax system would have a decidedly unnatural bias in favor of housing over all other forms of consumption. The existing tax operates as an excise on housing expenditures of about twenty per cent nationwide. The sales tax rate is generally around three per cent. Thus Netzer proposes taxation of housing expenditures at five per cent.

Another hybrid tax base system is that currently used in Germany. Farm and acreage lands are taxed on capitalized income, real estate is taxed on rental values, and a special tax is applied to vacant land suitable for development. ${ }^{134}$

\section{Proposed Solution}

The existing property tax system unintentionally and often unintelligently deviates from the norm of neutrality. While the property tax is by no means the sole cause of suboptimal land use, it is often a factor working in the wrong direction. The solution of this problem may take one of two possible forms. First, an effort could be made to conform the existing tax system to our notion of an ideal land use neutral tax. This 1935.

${ }^{131}$ Address by Peter Grim, Institute of Public Affairs, University of Virginia, July 10,

132 Netzer, The Property Tax and Alternatives in Urban Development, in 9 Recrowax Sctence Assoctation, Papers and Proceedings (1962).

133 D. Netzer, The Economacs of the Property Tax (1966), D. Netzer, Some Alternatives in Property Tax Reform, Nov. 4, 1966 (paper presented at the Tax Institute Symposium, Chicago, $\mathrm{mI}$.).

134 von Borries, Local Finance and Community Development, $30 \mathrm{~J}$. Asr. INsT. OF Pianners 34, 36 (1964). 
is not feasible. For example, to neutralize the tax in the central city, it would be necessary to reduce the high rates; this would force the city to reduce its budget and its public services. The net result would be to encourage further erosion of the tax base by forcing residents to move out faster.

A second solution involves an intentional and hopefully intelligent use of the taxing system as an instrument of planning. This would require a working partnership between planners, tax administrators, lawyers, and land economists. Under existing state uniformity laws, which require that all property be assessed on the sanie basis as other similar property, taxation can never be more than the bluntest of all possible planning tools. However, if we assume that these legal obstacles to refining taxation as an instrument of planning could be overcome, the following reforms seem advisable. In the central city, land should be taxed on the basis of one half of its site value, and improvements taxed on a net income basis determined by a capitahzation of income approach. In the suburbs, residents should be taxed for property oriented services on the basis of user charges. The problem of mercantilist zoning in the suburbs cannot be corrected by local taxation. The cure for mercantilist zoning lies in the expansion of the tax base along regional lines. A regional government could administratively handle the computation of user charges for property oriented services. It would seem desirable for a regional governinent to finance those services which are not property oriented on some basis other than the property tax; for example, schools could be financed through a school tax based on individual net worth. Another alternative would be use of the personal income rather than property value to finance regional nonproperty oriented services.

In the fringe areas, taxation should be on the capitalization of land income basis rather than on a market value basis only if the land is irrevocably devoted to farming. The two basic problems of the fringethat of conserving sufficient open space for future recreational needs and that of conserving top grade agricultural soil from being destroyed by suburban sprawl-cannot be solved by taxation alone. The solution to these problems in the fringe requires affirmative action by the legislature, either to purchase development rights and conservation easements, or to establish greenbelts through zoning.

Throughout the entire metropolitan area there should be a uniform land value increment tax imposed at the time of sale. In addition, a uniform five per cent tax on housing expenditures would be necessary to prevent undue favoring of owner occupied housing. This solution is not proposed as a perfect solution to all land use problems. It is only a model of a refined use of tax policy to deal with the problems of land 
use in a metropolitan area. The model is general in nature and not designed for specific implementation in any particular area. Each geographic area may have different land use needs.

\section{CONCLUSION}

The existing property tax system's effect on land use patterns within the metropolitan area creates social and political problems. In the central city such problems include: (1) a decline in the tax base as middle class residents moved to the suburbs, (2) increased population density, (3) increased service costs associated with obsolescence and wear, and (4) low per capita property values. These problems result in higher rates in most central cities because city government maintains services at a constant level rather than allowing them to decline with the tax base. Under the existing system high tax rates discourage new construction, remodeling, and replacement because the tax falls on improvements as well as land. The detrimental effects of the tax system are amplified by the assessment lag whicli runs adversely to the market.

The effects of taxation on land use are more difficult to analyze in the suburbs and fringe areas. Perhaps the fragmentary pattern of suburban government contributes to the formation of enclaves. However, mercantilist zoning might be caused by a desire to keep down rates on existing taxpayers by attracting new higl-base, low-cost taxpayers. In the fringe, sprawl causes higher taxes, and higher taxes in turn force premature development as farmers are taxed out of farming. Despite the lack of a clear causal relation between certain land use patterns and corresponding taxation, the two are interrelated. This interrelation requires a more comprehensive dialogue between land use planners and tax policy formulators than has heretofore existed. 


\section{APPENDIX +}

Effective Real Property Tax Rates in Selected Metropolitan Areas

\begin{tabular}{cccccc}
\hline \multirow{2}{*}{$\begin{array}{c}\text { General } \\
\text { Area }\end{array}$} & Central City & $\begin{array}{c}\text { Middle Aged } \\
\text { Suburbs }\end{array}$ & $\begin{array}{c}\text { New Rapid } \\
\text { Growth Suburbs }\end{array}$ & Endustrial & Estate \\
\hline North-East & Newark & Orange & Livingston & Teterboro & Essex Falls \\
New Jersey & $(4.9 \%)$ & $(3.9 \%)$ & $(2.9 \%)$ & $\begin{array}{c}(0.8 \%) \\
\text { Linden }\end{array}$ & $(2.9 \%)$ \\
& & & & $(1.5 \%)$ & \\
Milwaukee & Milwaukee & Shorewood & Brown Deer & West & Fox Point \\
Wisconsin & $(3.4 \%)$ & $(2.7 \%)$ & $(2.6 \%)$ & Milwaukee & (2.8\%) \\
& & & & $(2.0 \%)$ & \\
Boston & Boston & Belmont & Lexington & Everett & Weston \\
Mass. & $(6.6 \%)$ & $(1.9 \%)$ & $(3.5 \%)$ & $(1.8 \%)$ & $(2.2 \%)$ \\
Pittsburgh & Pittsburgh & Wilkinsburg & Penn Hills & Hounestead & Fox Chapel \\
Pa. & $(2.9 \%)$ & $(2.5 \%)$ & $(2.1 \%)$ & $(2.4 \%)$ & $(2.4 \%)$ \\
Los Angeles & Los Angeles & Huntington & Manhattan & Vernon & Beverly \\
So. Calif. & $(2.1 \%)$ & Park & Beach & $(1.7 \%)$ & Hills \\
& & $(1.8 \%)$ & $(1.9 \%)$ & & $(1.15 \%)$ \\
Bay Area & Oakland & Berkeley & Hayward & Emeryville & Hillsborough \\
No. Calif. & $(3.2 \%)$ & $(2.9 \%)$ & $(2.5 \%)$ & $(1.910 \%)$ & $(1.96 \%)$ \\
\hline
\end{tabular}

$\dagger$ The figures for the Northeastern New Jersey, Milwaukee, Boston, Pittsburgh, and Los Angeles areas are derived from J. Pickard, Taxation AND LAND USE IN MEtropolitan AND UrbaN AMrerica 37 (ULI Research Monograph No. 12, 1966). The figures for the Bay Area are based on extremely rough calculations by the author. These figures were computed by multiplying the tax rate by the ratio of assessed to market value. Alameda County in 1966-1967 used two different ratios: residential property (21.6\%) and commercial, or industrial property $(28.0 \%)$. The tax rates are computed by code areas which are not broken down into residential or commercial classification. In the Central City of Oakland, code areas 17-001 \& 17-003 with a rate of $\$ 11.53$, the $28 \%$ ratio was used. In Berkeley, code area $13-000$ with a rate of $\$ 13.38$, the $21.6 \%$ ratio was used. In Hayward with eighty-eight code areas, 10 were chosen with a rate of $\$ 11.15$ and the $21.6 \%$ ratio applied. In Emeryville, code areas $14-000$ \& $14-001$ with a rate of $\$ 6.82$, the $28 \%$ ratio was used. In San Mateo County property is umiformly assessed at $25 \%$. In Hillsborough, code area 6-001 with a rate of $\$ 7.72$ the $25 \%$ ratio was used. 


\section{California Law Review}

\begin{tabular}{lll}
\hline Vol. 55 & AUGUST 1967 & No. 3 \\
\hline \hline
\end{tabular}

BOARD OF EDITORS

Editor-in-Chief

Peter Kay Westen

Managing Editor

JOHN J. BENTLEY III

Article Editors

ALrSON M. GREY

John F. Pritchard
Book Review Editor

WIILIAM Roger Strejow

Executive Editor

DanIex U. SMITH

Research and Chief

Note \& Comment Editor

George Richard Poemerer

Note \& Comment Editors

PAUL B. Bergman

STEPHEN J. Bisgeter

Trmothy Dreyrus

MTCeatex C. Ferguson

\author{
Eamen Hali Guggenmime \\ Donatas Januta \\ JeFFrey David Sober \\ WILITAM T. Vurowich
}

Bruce Babcock, JR. JEFEREY F. BECK

WIILIAMT S. BETHARD Lawrence L. Curtice Steven H. GoLDFARB Robert ErNest Gyemant

SaMmoet Bassett AbBot KENNETH J. AdELSON Robert D. Byrne, Jr. JAMES H. CHRISTIANSEN KENNETH A. CoHEN Steven W. Errczson W. ERrC FAITH RICHARD N. FISHER
Associate Editors

RICHard V. HaLI

ALAN E. HARRIS

Dovglas A. Haydel

JOHN E. HUERTA

WIILIAMM S. BETHARD

WITITAM L. JAEGER

\section{Candidates}

Max W. J. Graitair, Jr. Patricta A. Muszynske

PAUL HARRIS

Jomn A. Hoskns

RICHARD I. LEHER

A. KetTh Lesar

Michaed H. Marcus

LEONARD I. MARGOLIS

ROpert

JoHN K. MORRIS

$$
\begin{aligned}
& \text { Student Contributor } \\
& \text { ALAN E. LAND } \\
& \text { General Secretary } \\
& \text { Rosemary KENNEDY }
\end{aligned}
$$

Blande Covington Janta Michaed JUSTin MYers Mark ReUTLINGER Dougras M. Schwab JANET FRTEDMan STANSBY Kristine Mary StrachaN Clayton C. Patrick John M. Poswate JAAIES E. REed Barbara A. Ritns ErIC A. SeItz Stuart P. Tobisman Davm S. WeIssbrodT

\section{3}

